\title{
An early Miocene spatangoid assemblage on a submarine volcanic ash dune from Patagonia (Argentina)
}

\author{
E.E. Palópolo ${ }^{\text {a,b, }}$, A. Kroh ${ }^{c}$, M. Harzhauser ${ }^{c}$, M. Griffin ${ }^{\mathrm{d}}$, S. Casadio ${ }^{\mathrm{a}, \mathrm{b}}$, N. Carmona ${ }^{\mathrm{a}, \mathrm{b}}$

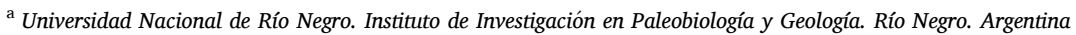 \\ ${ }^{\mathrm{b}}$ IIPG. UNRN. Consejo Nacional de Investigaciones científicas y Tecnológicas (CONICET). Av. Roca 1242, (R8332EXZ) General Roca, Río Negro, Argentina \\ ${ }^{\mathrm{c}}$ Naturhistorisches Museum Wien (NHMW), Burgring 7, 1010, Vienna, Austria \\ ${ }^{\mathrm{d}}$ División Paleozoología Invertebrados, Facultad de Ciencias Naturales y Museo, Universidad Nacional de La Plata, Edificio Anexo Laboratorios del Museo (Lab. 110), \\ 120 y 60, 1900, La Plata, Buenos Aires, Argentina
}

\section{A R T I C L E I N F O}

\section{Keywords:}

Brisaster

Echinoid assemblage

Spatangoida

Santa cruz province

Miocene

\begin{abstract}
A B S T R A C T
A single $27 \mathrm{~m}^{2}$ spatangoid-dominated bed yielding 65 specimens from the Punta Entrada Member of the Monte León Formation was studied. Most of the fossils were preserved oral side down, with clusters of spines attached to the tests, showing no evidence of preburial transport. The deposit is interpreted as the result of sedimentation in a subtidal environment coeval with strong and continuous explosive volcanic activity, indicated by the significant amount of volcanic ash within the sediment. Echinoids assigned to Brisaster aff. B. iheringi De Loriol, 1902 colonized a distal part of the subtidal environment dominated by large-scale migrant bedforms. During dormant periods, it was characterized by low energy and low sedimentation rate, allowing colonization by several groups of infaunal organisms. Upon reactivation of sediment migration, a high sedimentary influx trapped the echinoids and prevented them from escaping.
\end{abstract}

\section{Introduction}

Spatangoids are a monophyletic group of fossil and extant irregular echinoids known to occur in rocks as early as Barremian (Early Cretaceous) (Villier et al., 2004; Stockley et al., 2005; Kroh and Smith, 2010). The Order Spatangoida comprises ca. 170 genera, grouped in 25 different families, eight of which include only fossil representatives (Kroh and Mooi, 2018). Most of them are infaunal, today inhabiting all oceans of the world (Stockley et al., 2005).

As active soft-substrate burrowers, spatangoids are considered among the most important trace producers in modern oceans (Belaústegui et al., 2017). The trace fossils Scolicia and Bichordites are attributed to the locomotion activity of spatangoids within the substrate (De Gibert and Goldring, 2007, 2008).

Many spatangoids have thin-walled tests that make them prone to breakage and disarticulation, but their burrowing habit accounts for the fact that the fossil record of irregular echinoids is better than that of regular echinoids (Kier, 1977), despite the fact that the latter are more diverse today (and possibly were in the past too). Well preserved spatangoid-dominated assemblages are the result of several sedimentary and taphonomic conditions associated with their habitats (i.e., rapid final burial in a thick, fine-grained sediment, dysoxic or anoxic conditions after burial and low water temperature; Mancosu and Nebelsick, 2016, and references therein). These assemblages were documented globally in Cenozoic deposits (Kroh and Nebelsick, 2003; Mancosu et al., 2015; Mancosu and Nebelsick, 2017; Carmona et al., 2020 and references therein), and each represents a valuable opportunity to understand their paleoecological and taphonomic features.

The family Schizasteridae Lambert, 1905, currently includes 23 genera and is considered a phylogenetically derived family of spatangoids (Stockley et al., 2005). The earliest record of this family is from the early Cenomanian and it underwent further diversification during the Late Cretaceous and the early Paleogene. Schizasterids are widespread within Miocene sedimentary successions of all continents. They show a cosmopolitan distribution and belong to the echinoderm taxa most mentioned in the literature about the Miocene (Jesionek-Szymañska, 1987; Khaksar and Moghadam, 2007; Kroh, 2007, 2010 and references therein; Holmes, 2014; Stara et al., 2016; Elattaar, 2018; Martínez and del Río, 2017; among others).

In Argentina, the fossil record of the Spatangoida is restricted to Late Cretaceous (Maastrichtian) to early Miocene rocks. In addition to the Patagonian species described in the 19th and early 20th centuries by von

\footnotetext{
* Corresponding author. Universidad Nacional de Río Negro. Instituto de Investigación en Paleobiología y Geología. Río Negro. Argentina.

E-mail address: eepalopolo@unrn.edu.ar (E.E. Palópolo).
} 


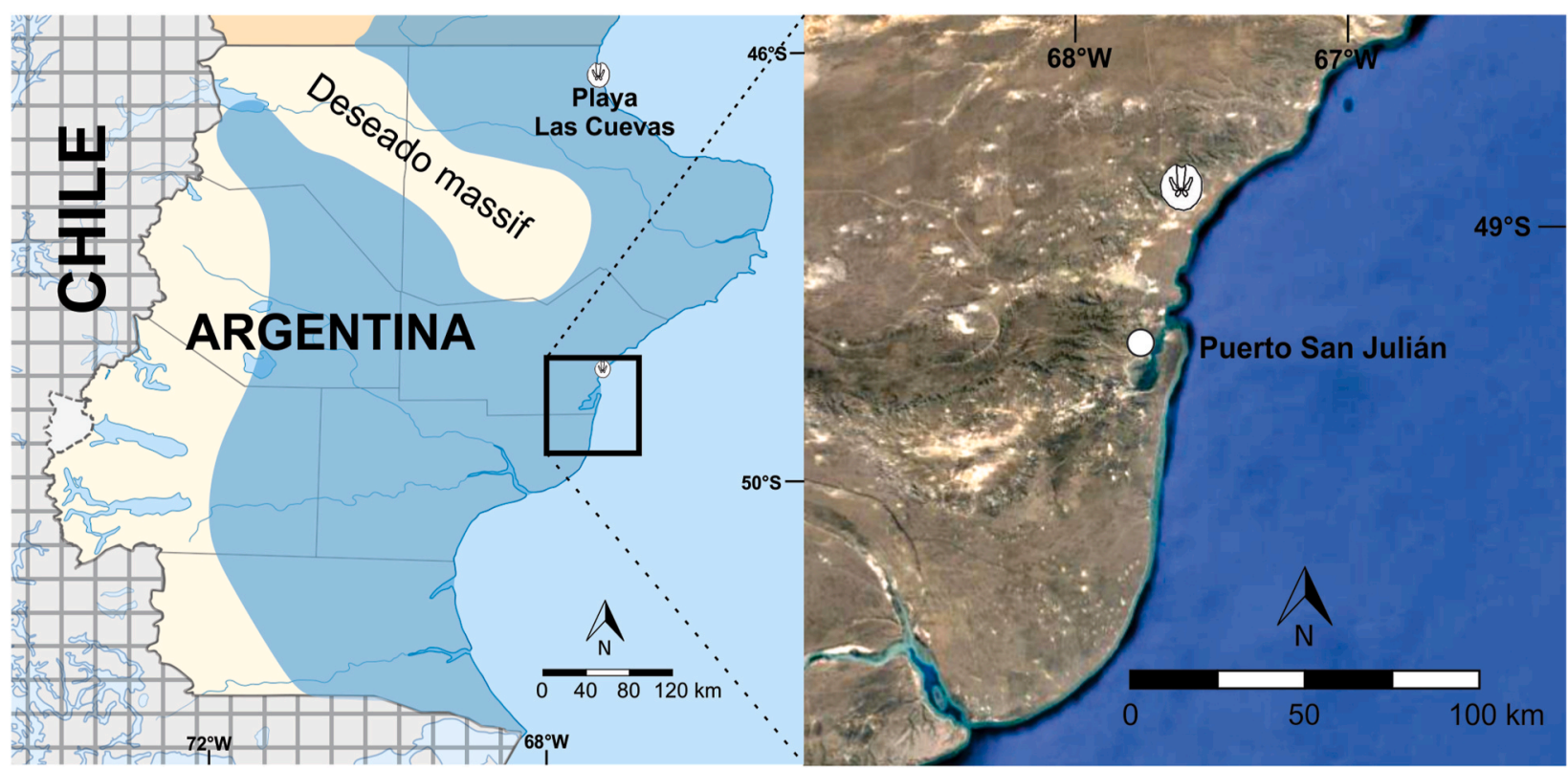

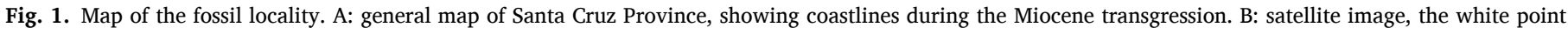

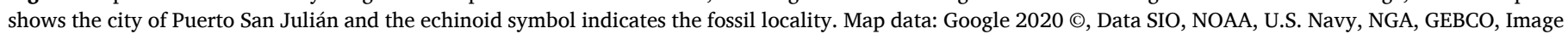
Landsat/Copernicus.

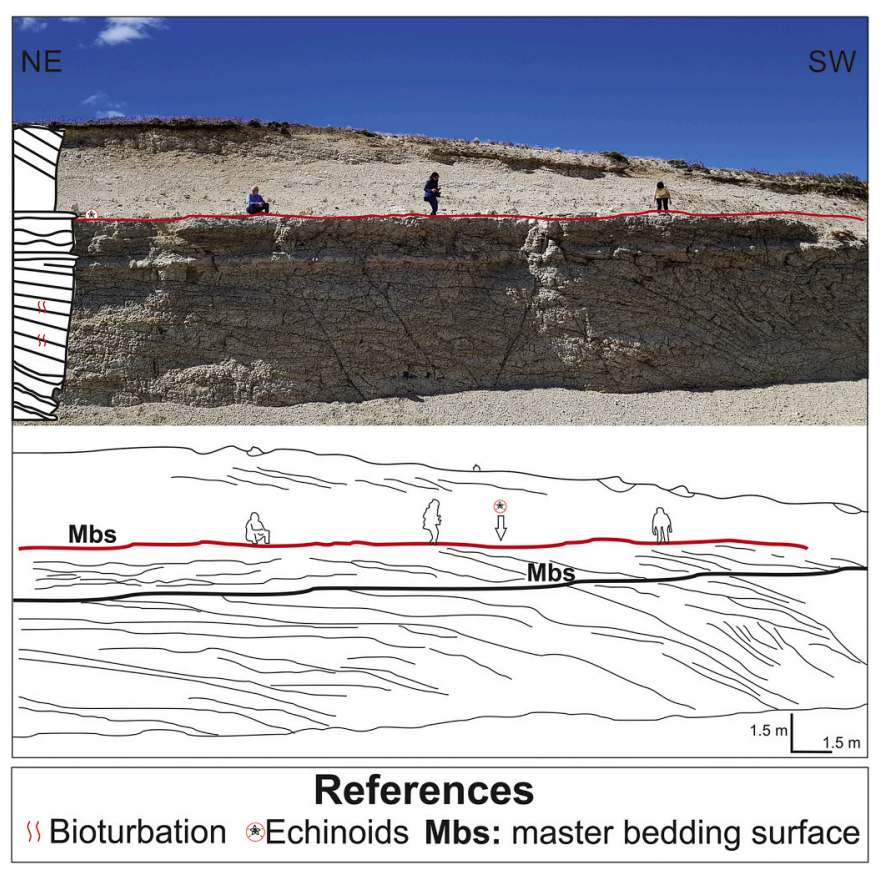

Fig. 2. General view (top) and diagram (bottom) of the outcrop along National Route 3, $40 \mathrm{~km}$ north of the city of San Julián (Santa Cruz Province). Red line indicates the studied fossiliferous layer.

Ihering (1897), De Loriol (1902), Ortmann (1902) and Bernasconi (1961), during the last fifteen years eleven additional species were documented for the Roca (Maastrichtian-Danian), Salamanca (Danian), and Chenque (Miocene) formations (Parma and Casadío, 2005; del Río et al., 2007; Martínez et al., 2011; Parma, 2012; Martínez and del Río, 2017).

Although these studies improved the knowledge of the group in Argentina, a systematic revision of the Patagonian spatangoid species is still missing.

The aim of this paper is to report a new Miocene record of the family
Schizasteridae from the Monte León Formation in Patagonia (Argentina) and to discuss its taphonomic and paleoecological implications.

\section{Geological settings}

Fossils were found in an artificial outcrop of the Monte León Formation along National Route 3, $40 \mathrm{~km}$ North of Puerto San Julián, Santa Cruz Province (GPS Geographic Coordinates: $-48.956^{\circ}$; $-67.648^{\circ}$; see Figs. 1 and 2).

Late Cretaceous to early Neogene periodic marine transgressions covered large areas of Patagonia and left thick fossil-bearing marine deposits. The Cenozoic marine deposits in the area surrounding Puerto San Julián (Santa Cruz Province) were first described by Darwin (1846) and are composed mostly of volcanically derived and poorly indurated rocks including tuffaceous sandstones, siltstones, and massive tuff layers. The siltstones and sandstones are intercalated with calcareous, fossil-rich layers (Parras and Casadío, 2005, 2006; Crawford et al., 2008; Malumián and Náñez, 2011; Parras et al., 2012; Cuitiño et al., 2018).

Oligocene to early Miocene marine rocks exposed along the coast of Santa Cruz south of the Deseado Massif in southern Patagonia are included in the San Julián and the overlying Monte León formations. The Monte León Formation (early Miocene) is about 180-200 m thick and consists of siltstone and fine-grained sandstone with a high proportion of pyroclastic material arising from contemporaneous volcanism in the Andean volcanic arc (Crawford et al., 2008). The Monte León Formation contains numerous accumulations of fossil invertebrates (del Río, 2004; Parras and Griffin, 2009; Casadio and Griffin, 2009; Parras et al., 2012; Cuitiño et al., 2018; Pineda-Salgado et al., 2018), and different depositional paleoenvironments were postulated for the unit, including a coastal environment (Echevarría, 2002) and hyposaline marsh and prodelta deposit (Olivera et al., 1994).

According to Parras and Griffin (2009), in the studied area the Monte León Formation records facies ranging from inner shelf to subtidal at the base to intertidal towards the top. The rocks containing the echinoids studied here are included in the lower part of the Monte León Formation (Panza et al., 1994; Parras et al., 2012). The rocks are friable, poorly indurated, and can be readily disaggregated. Thin sections of samples show that pyroclastic material is a dominant component of the rock, consisting mainly of minute shards of partially to fully devitrified 


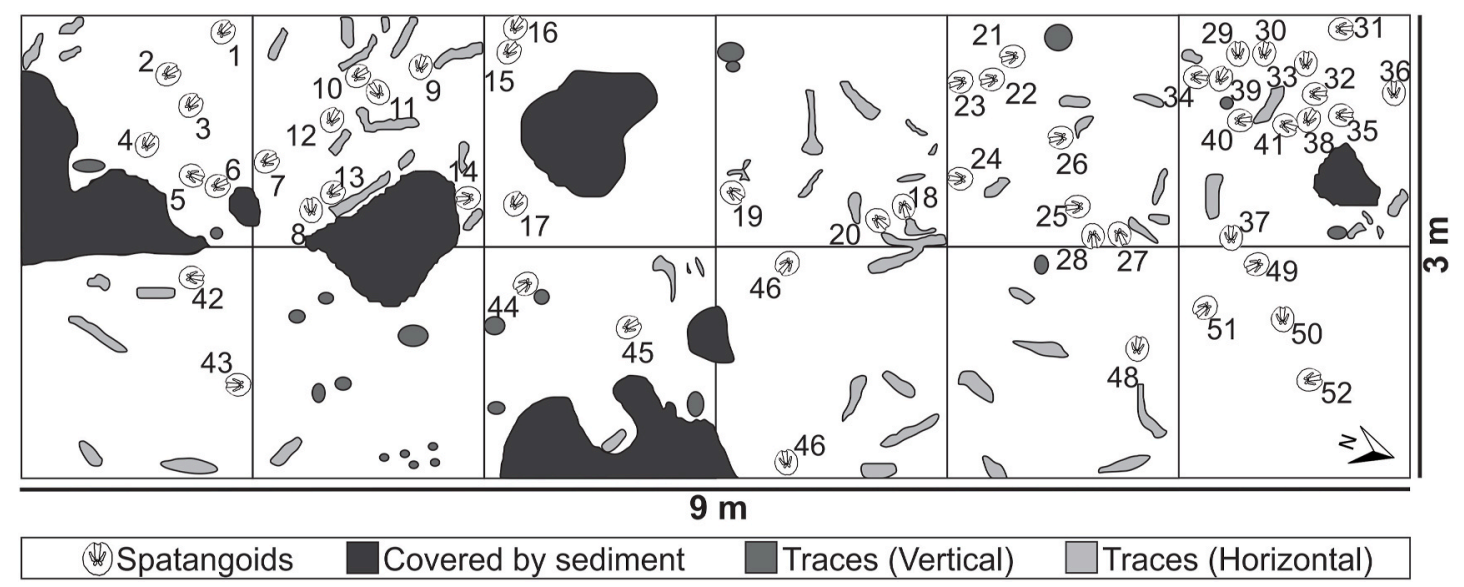

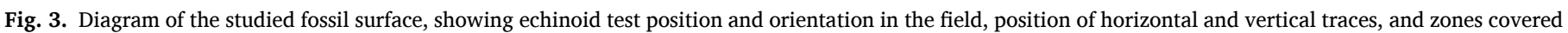
by overlying sediment.

volcanic glass and volcanically derived altered clays.

The succession containing the bed with echinoids is the result of sedimentation in a subtidal environment coeval with strong and continuous explosive volcanic activity (Crawford et al., 2008). It begins with a $7.50 \mathrm{~m}$ thick, cross-bedded, yellowish-white, fine-to medium-grained sandstone. Within the stratum, there are two cross-stratified beds, separated by a 15-cm-thick, highly indurated, subhorizontal truncation surface (Mbs: master bedding surface, Fig. 2). The second master bedding surface (Mbs), yielding the spatangoid tests, is a 5-10 $\mathrm{cm}$ thick heavily consolidated fine sandstone. The trace fossils present in this bed include specimens assigned to Thalassinoides, Arenicolites, Planolites, Scolicia, Ophiomorpha, and Skolithos. Above the second Mbs, cross-bedded stratification continues with a poorly sorted, medium-grained sandstone with approximately $30 \%$ of silt content. Finally, the succession ends with a 30 -cm-thick, medium-to fine-grained, laminated sandstone.

Sedimentary structures (i.e., cross stratified thick beds separated by highly indurated subhorizontal truncation surfaces) and the aforementioned trace fossil suite could indicate actively migrating large-scale bedforms in an open marine setting, in which tidal currents were the dominant sedimentary processes. In subtidal areas with actively migrating large-scale bedforms, energetic conditions preclude the development of highly diverse benthic communities (Desjardins et al., 2012).

Under continuous migration of the sediment, the colonization window is constrained (Pollard et al., 1993), allowing bioturbation only by opportunistic organisms adapted to high-energy conditions. Extensive colonization by echinoids and high diversity of fossil traces is interpreted to be associated with discontinuous migration or dormant forms (Desjardins et al., 2012).

\section{Material and methods}

A surface layer of $9 \times 3 \mathrm{~m}\left(27 \mathrm{~m}^{2}\right)$ yielding spatangoid echinoids was found in an artificial outcrop adjoining National Route 3 . The studied surface was divided into 12 quadrangles measuring $1.5 \times 1.5 \mathrm{~m}\left(2.25 \mathrm{~m}^{2}\right.$ each) to record the position of the fossils in the field (Fig. 3). Orientation of the anterior ambulacral groove was measured for 52 specimens preserved in life position (i.e. specimens still partially embedded in the sediment, almost complete, and oriented with their oral side downwards). Forty-five of them were collected in the field. In addition, 15 loose specimens were collected as float from scree.

Fossils were temporarily exported to the Natural History Museum of Vienna for cleaning and preparation. Temporary fossil export was authorized by Gobierno de la Provincia de Santa Cruz, Museo Argentino de Ciencias Naturales (IF-2018-58231802-APN- MACN\#CONICET) and
AFIP (Subrégimen de exportación temporaria sin modificación 18/073/ ET2/000311/V). Adhering sediment was removed manually using scalpels, needles, and chisels, as well as with pneumatic preparation tools, which also allowed removal of still attached spines that partly obscured relevant morphological features. To remove the fine sediment deposited in the petals and the oral surface a RUBY® sandblaster using sodium carbonate powder with $50 \mu \mathrm{m}$ grain size at 30 psi was employed. In addition, iron powder of $50 \mu \mathrm{m}$ grain size was employed at $22 \mathrm{psi}$ to clean the oral surface of specimens in which sediment was especially indurated.

Specimens were measured with a digital caliper (error: 0.01), following the scheme employed by Stara et al. (2012) (Table 1). For each quantitative character, descriptive statistical parameters were calculated. Position of echinoids was plotted using Inkscape 0.92 .3 and exported into GeoGebra Classic 5.0.518.0-d (December 20, 2018) to extract the point coordinates. Poisson and Clark Evans tests were performed to identify clustering patterns of echinoids on the surface. Parameters were calculated based on 999 simulations of CSR with fixed $n$. Kernel smoothed density was calculated and plotted to observe aggregation patterns. Furthermore, to determine if the fossils had any preferential orientation in the field, a rose diagram and a Rayleigh Test for preferred orientation was made. To test morphological differences with the specimens published by Martínez and del Río (2017) and Carmona et al. (2020), a Linear Discriminant Analysis (LDA) was performed, including the morphometric measurements of all the echinoids mentioned in those publications. The LDA finds the component axes that maximize the separation between multiple classes (Pérez López, 2004). In this case, the purpose is to find if all the specimens considered to be Brisaster iheringi in Patagonia belong to the same species or not, using morphometric data. Tests were performed with LibreOfficeCalc 6.1.0.3 (The Document Foundation, 2020), Past 3.20 (Hammer et al., 2001) and R 3.5.2 (R Development Core R Core Team, 2014) ( $\alpha=0.05$ ). Plots were made with Past 3.20 (Hammer et al., 2001) and GeoRose 0.5.1 (Yong Technologies Inc., 2015).

Two thin sections of supraambital plates from interambulacrum 2 of one specimen allowed an analysis of taphonomic features. Mineralogical features were observed with Zeiss ${ }^{\circledR}$ Discovery V20 and Nikon ${ }^{\circledR}$ Eclipse E200 Microscopes using normal and polarized light. Five bulk samples were taken in the field in order to investigate the microfauna of the sediments containing the spatangoid assemblage studied. After drying, the bulk sample was disaggregated with $10 \%$ hydrogen peroxide, dried at $40{ }^{\circ} \mathrm{C}$ and sieved into 250, 125 and $63 \mu \mathrm{m}$ fractions. The other four sediment samples were treated in the same way and sieved into 2000 , $1000,500,250,125,62$, and $<62 \mu \mathrm{m}$ fractions.

Photographs were taken using a Zeiss ${ }^{\circledR}$ AxioCam Mrc 5 (attached to a Zeiss Stereo Discovery V20 Microscope), Nikon ${ }^{\circledR}$ D5200, and Nikon ${ }^{\circledR}$ 
Table 1

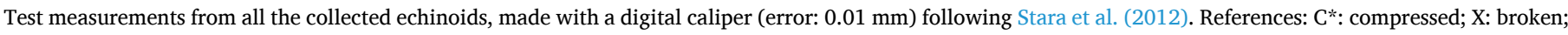

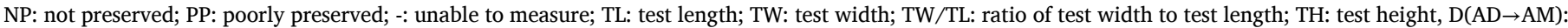

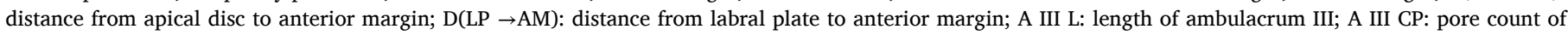

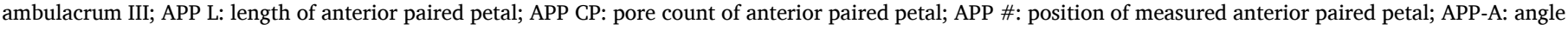

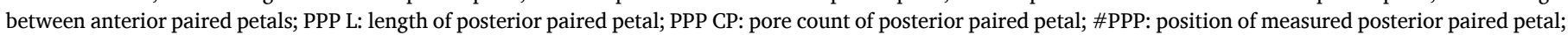
PPP-A: angle between posterior paired petals; MPM-PI: Museo Regional Provincial Padre Jesús Molina, Río Gallegos, Santa Cruz Province, Argentina.

\begin{tabular}{|c|c|c|c|c|c|c|c|c|c|c|c|c|c|c|c|c|}
\hline \# Collection & TL & TW & $\begin{array}{l}\text { TW/ } \\
\text { TL }\end{array}$ & $\mathrm{TH}$ & $\begin{array}{l}\mathrm{D} \\
(\mathrm{AD} \rightarrow \mathrm{AM})\end{array}$ & $\begin{array}{l}\mathrm{D}(\mathrm{LP} \\
\rightarrow \mathrm{AM})\end{array}$ & $\begin{array}{l}\text { A III } \\
\text { L }\end{array}$ & $\begin{array}{l}\text { A III } \\
\text { CP }\end{array}$ & $\begin{array}{l}\text { APP } \\
\text { L }\end{array}$ & $\begin{array}{l}\text { APP } \\
\text { CP }\end{array}$ & $\begin{array}{l}\text { APP } \\
\#\end{array}$ & $\begin{array}{l}\text { APP- } \\
\text { A }\end{array}$ & $\begin{array}{l}\text { PPP } \\
\mathrm{L}\end{array}$ & $\begin{array}{l}\text { PPP } \\
\mathrm{CP}\end{array}$ & \#PPP & $\begin{array}{l}\text { PPP- } \\
\text { A }\end{array}$ \\
\hline $\begin{array}{c}\text { MPM-PI- } \\
19236\end{array}$ & 47.8 & 44.4 & 0.93 & NP & NP & $\mathrm{NP}$ & NP & - & NP & - & - & - & NP & - & - & - \\
\hline $\begin{array}{c}\text { MPM-PI- } \\
19237\end{array}$ & 46.7 & 44.4 & 0.95 & NP & 32.4 & 5.6 & 28.3 & PP & 23.1 & $\begin{array}{l}32 ? / \\
36\end{array}$ & II/IV & 75.2 & 8.5 & $\mathrm{PP}$ & I & 95.0 \\
\hline $\begin{array}{c}\text { MPM-PI- } \\
19238\end{array}$ & $\mathrm{X}$ & $\mathrm{X}$ & - & NP & NP & $\mathrm{NP}$ & NP & - & NP & - & - & - & NP & - & - & - \\
\hline $\begin{array}{c}\text { MPM-PI- } \\
19239\end{array}$ & $\mathrm{X}$ & $\mathrm{X}$ & - & NP & NP & 7.9 & 30.3 & PP & 22.7 & PP & II & - & NP & - & - & - \\
\hline $\begin{array}{c}\text { MPM-PI- } \\
19240\end{array}$ & 53.3 & 50.2 & 0.94 & 22.2 & 35.1 & $\mathrm{NP}$ & 34 & PP & 25.7 & 34 & IV & 79.7 & 12.9 & PP & I & 84.5 \\
\hline $\begin{array}{c}\text { MPM-PI- } \\
19241\end{array}$ & 46.1 & 44.9 & 0.97 & NP & 32.3 & 5.3 & 29.2 & $36+$ & 21.3 & $\begin{array}{l}34 / \\
34 ?\end{array}$ & II/IV & 80.9 & 9.2 & PP & I & 89.2 \\
\hline $\begin{array}{l}\text { MPM-PI- } \\
19242 \mathrm{a}\end{array}$ & 45.5 & 42.6 & 0.94 & NP & 29.4 & 8.1 & 26.8 & PP & 21 & $27 ?$ & II & 78.2 & 9 & 18 & I & 85.0 \\
\hline $\begin{array}{l}\text { MPM-PI- } \\
19242 \mathrm{~b}\end{array}$ & $\mathrm{X}$ & $C^{*}$ & - & NP & 30.5 & $\mathrm{NP}$ & 28.3 & PP & 21.2 & 33 & IV & 82.7 & NP & - & - & - \\
\hline $\begin{array}{c}\text { MPM-PI- } \\
19243\end{array}$ & 43.7 & 42.7 & 0.98 & 20.7 & 25.1 & 5.1 & 24.9 & PP & 19.6 & $\mathrm{PP}$ & II & 83.8 & 8.3 & PP & I & 97.4 \\
\hline $\begin{array}{r}\text { MPM-PI- } \\
19244\end{array}$ & 39.1 & 41.1 & 1.05 & NP & NP & $\mathrm{NP}$ & $\mathrm{X}$ & - & $\mathrm{X}$ & - & - & - & $\mathrm{X}$ & - & - & - \\
\hline $\begin{array}{c}\text { MPM-PI- } \\
19245\end{array}$ & 47.9 & 45.7 & 0.95 & 18.9 & 27.5 & 8.9 & 25.9 & 40 & 20.2 & 34 & II & 79.9 & 10.4 & $18 / 16$ & $\mathrm{I} / \mathrm{V}$ & 84.2 \\
\hline $\begin{array}{c}\text { MPM-PI- } \\
19246\end{array}$ & 45.2 & 45.2 & 1 & 15.8 & 26.8 & 9.4 & 23.8 & PP & 20.5 & PP & II & 85.5 & PP & NP & - & 81.6 \\
\hline $\begin{array}{c}\text { MPM-PI- } \\
19247\end{array}$ & 50.9 & 46.6 & 0.92 & 18.1 & 29.4 & 11.7 & 25.5 & PP & 22.7 & $\begin{array}{l}32 ? / \\
32 ?\end{array}$ & II/IV & 84.5 & 10 & $\begin{array}{l}18 / \\
16 ?\end{array}$ & $\mathrm{I} / \mathrm{V}$ & 79.0 \\
\hline $\begin{array}{c}\text { MPM-PI- } \\
19248\end{array}$ & $\mathrm{X}$ & $\mathrm{X}$ & - & NP & $\mathrm{X}$ & $\mathrm{NP}$ & $\mathrm{X}$ & NP & $X$ & - & $X$ & - & $\mathrm{X}$ & - & $\mathrm{X}$ & - \\
\hline $\begin{array}{c}\text { MPM-PI- } \\
19249\end{array}$ & 47.4 & 46.3 & 0.98 & 19.3 & 30.8 & 5.6 & 30.2 & PP & 21 & $\mathrm{NP}$ & II & 86.2 & 9.2 & PP & I & 85,7 \\
\hline $\begin{array}{c}\text { MPM-PI- } \\
19250\end{array}$ & 44.7 & 45.9 & 1.03 & 22.2 & 24.4 & 5.9 & 24.6 & PP & 20 & $\mathrm{PP}$ & II & - & 9.1 & $\mathrm{PP}$ & I & - \\
\hline $\begin{array}{c}\text { MPM-PI- } \\
19251\end{array}$ & 45 & 43.6 & 0.97 & 20.7 & 28.8 & 7.5 & 25.2 & PP & 22.7 & $37 / 38$ & II/IV & 79.7 & 8.9 & $16 / 15$ & $\mathrm{I} / \mathrm{V}$ & 90.1 \\
\hline $\begin{array}{c}\text { MPM-PI- } \\
19252\end{array}$ & 44.5 & 42.3 & 0.95 & NP & NP & $\mathrm{NP}$ & NP & - & NP & - & - & - & NP & - & - & - \\
\hline $\begin{array}{c}\text { MPM-PI- } \\
19253\end{array}$ & $\mathrm{X}$ & $\mathrm{X}$ & - & $\mathrm{X}$ & NP & $\mathrm{NP}$ & $\mathrm{NP}$ & - & $\mathrm{NP}$ & - & - & - & $\mathrm{NP}$ & - & - & - \\
\hline $\begin{array}{r}\text { MPM-PI- } \\
19254\end{array}$ & 46.4 & 46.7 & 1.01 & 19.1 & 27.6 & 7.3 & 26.3 & 42 & $\mathrm{PP}$ & NP & - & - & 9.1 & $\mathrm{PP}$ & I & - \\
\hline $\begin{array}{c}\text { MPM-PI- } \\
19255\end{array}$ & 43.3 & 43.9 & 1.01 & 20 & 26.7 & PP & 24.1 & PP & 18.8 & PP & II & - & 6.3 & PP & I & - \\
\hline $\begin{array}{c}\text { MPM-PI- } \\
19256\end{array}$ & 42.6 & 42.7 & 1.00 & 18.5 & 24.1 & 7.8 & 24 & PP & 19.3 & $\mathrm{PP}$ & II & - & 8.6 & PP & - & - \\
\hline $\begin{array}{c}\text { MPM-PI- } \\
19257\end{array}$ & 44.9 & 44.4 & 0.99 & 17.2 & 26.3 & $\mathrm{NP}$ & 28 & PP & 21.5 & PP & II & - & PP & NP & - & - \\
\hline $\begin{array}{c}\text { MPM-PI- } \\
19258\end{array}$ & 44.4 & 43.1 & 0.97 & NP & 31.1 & $\mathrm{NP}$ & 25.7 & PP & 19.9 & $\mathrm{PP}$ & II & - & 9.4 & $\mathrm{PP}$ & I & - \\
\hline $\begin{array}{c}\text { MPM-PI- } \\
19259\end{array}$ & 41.3 & 38.7 & 0.94 & 19.1 & 25.9 & $\mathrm{NP}$ & 22.7 & PP & $\mathrm{PP}$ & PP & - & 80.8 & PP & - & - & 93.4 \\
\hline $\begin{array}{c}\text { MPM-PI- } \\
19260\end{array}$ & 48.6 & 45.2 & 0.93 & - & 30.8 & 10 & 26.5 & PP & 20.4 & 32 & II & 76.6 & 11.3 & $16 ?$ & I & 79.1 \\
\hline $\begin{array}{c}\text { MPM-PI- } \\
19261\end{array}$ & 40.7 & 39.6 & 0.97 & 16.3 & 29.4 & $\mathrm{NP}$ & 27.3 & $\mathrm{PP}$ & 18.5 & PP & II & 79.5 & 8.8 & $\mathrm{PP}$ & I & 87.0 \\
\hline $\begin{array}{c}\text { MPM-PI- } \\
19262\end{array}$ & 51.9 & 49.2 & 0.95 & NP & NP & 9.4 & 25 & NP & 23.4 & 35 & II & - & 9.8 & 16 & I & 90.1 \\
\hline $\begin{array}{c}\text { MPM-PI- } \\
19263\end{array}$ & $\mathrm{X}$ & $\mathrm{X}$ & - & $\mathrm{X}$ & NP & NP & NP & - & NP & - & - & - & NP & - & - & - \\
\hline $\begin{array}{r}\text { MPM-PI- } \\
19264\end{array}$ & 52.8 & 47.6 & 0.90 & NP & 32.9 & 10.2 & 26.6 & 40 & 21.3 & $\begin{array}{l}36 / \\
32 ?\end{array}$ & II/IV & 77.7 & 9.3 & $\mathrm{PP}$ & I & 83.3 \\
\hline $\begin{array}{c}\text { MPM-PI- } \\
19265\end{array}$ & 49.3 & 47 & 0.95 & 21.8 & 29.8 & 8.9 & 24.9 & PP & 21.9 & $\mathrm{PP}$ & II & 85.7 & 10.4 & $\mathrm{PP}$ & I & 85.8 \\
\hline $\begin{array}{c}\text { MPM-PI- } \\
19266\end{array}$ & 43.1 & 42.9 & 0.99 & NP & NP & 7.9 & NP & - & NP & - & - & - & NP & - & - & - \\
\hline $\begin{array}{c}\text { MPM-PI- } \\
19267\end{array}$ & 44 & 41.9 & 0.95 & NP & 30.3 & $\mathrm{NP}$ & 32.7 & 40 & 23.4 & $34 ?$ & II & 81.2 & $\mathrm{NP}$ & - & - & - \\
\hline $\begin{array}{c}\text { MPM-PI- } \\
19268\end{array}$ & $X$ & $\mathrm{X}$ & - & NP & NP & NP & NP & - & NP & - & - & - & NP & - & - & - \\
\hline
\end{tabular}


Table 1 (continued)

\begin{tabular}{|c|c|c|c|c|c|c|c|c|c|c|c|c|c|c|c|c|}
\hline \# Collection & TL & TW & $\begin{array}{l}\text { TW/ } \\
\text { TL }\end{array}$ & $\mathrm{TH}$ & $\begin{array}{l}\mathrm{D} \\
(\mathrm{AD} \rightarrow \mathrm{AM})\end{array}$ & $\begin{array}{l}\mathrm{D}(\mathrm{LP} \\
\rightarrow \mathrm{AM})\end{array}$ & $\begin{array}{l}\text { A III } \\
\text { L }\end{array}$ & $\begin{array}{l}\text { A III } \\
\text { CP }\end{array}$ & $\begin{array}{l}\text { APP } \\
\text { L }\end{array}$ & $\begin{array}{l}\text { APP } \\
\text { CP }\end{array}$ & $\begin{array}{l}\text { APP } \\
\#\end{array}$ & $\begin{array}{l}\text { APP- } \\
\text { A }\end{array}$ & $\begin{array}{l}\text { PPP } \\
\text { L }\end{array}$ & $\begin{array}{l}\text { PPP } \\
\mathrm{CP}\end{array}$ & \#PPP & $\begin{array}{l}\text { PPP- } \\
\text { A }\end{array}$ \\
\hline $\begin{array}{c}\text { MPM-PI- } \\
19269\end{array}$ & $\mathrm{X}$ & $\mathrm{X}$ & - & $\mathrm{X}$ & NP & NP & $C^{*}$ & NP & PP & NP & - & - & NP & - & - & - \\
\hline $\begin{array}{c}\text { MPM-PI- } \\
19270\end{array}$ & $\mathrm{X}$ & $\mathrm{C}^{*}$ & - & $\mathrm{X}$ & $\mathrm{X}$ & $C^{*}$ & $\mathrm{C}^{*}$ & PP & $\mathrm{C}^{*}$ & PP & - & $C^{*}$ & NP & - & - & - \\
\hline $\begin{array}{c}\text { MPM-PI- } \\
19271\end{array}$ & 38.9 & 38.8 & 0.99 & NP & 29.6 & $\mathrm{PP}$ & $C^{*}$ & NP & PP & NP & - & NP & NP & - & - & - \\
\hline $\begin{array}{c}\text { MPM-PI- } \\
19272\end{array}$ & $C^{*}$ & $\mathrm{C}^{*}$ & - & $\mathrm{C}^{*}$ & - & $C^{*}$ & $C^{*}$ & NP & PP & NP & - & - & NP & - & - & - \\
\hline $\begin{array}{r}\text { MPM-PI- } \\
19273\end{array}$ & 46.9 & 44.1 & 0.94 & 20.6 & 28.7 & 7.2 & 25.6 & $\mathrm{PP}$ & 23.2 & 36 & II & - & 10.3 & 18 & I & - \\
\hline $\begin{array}{r}\text { MPM-PI- } \\
19274\end{array}$ & 47 & 45.6 & 0.97 & 21.3 & 28 & 8.7 & 25.7 & $\mathrm{PP}$ & 19.6 & $36 / 34$ & II/IV & 84,9 & 9.1 & 18 & I & 84.4 \\
\hline $\begin{array}{r}\text { MPM-PI- } \\
19275\end{array}$ & $\mathrm{X}$ & $\mathrm{X}$ & - & $\mathrm{X}$ & NP & NP & 24 & 39 & 19.2 & 34 & IV & - & NP & - & - & - \\
\hline $\begin{array}{l}\text { MPM-PI- } \\
19276 a\end{array}$ & $\mathrm{X}$ & $\mathrm{X}$ & - & NP & 30.7 & NP & 27.4 & PP & 20.9 & 30 & IV & 83.9 & NP & - & - & - \\
\hline $\begin{array}{l}\text { MPM-PI- } \\
19276 \mathrm{~b}\end{array}$ & 40.1 & 41.8 & 1.04 & NP & NP & 10.1 & NP & - & NP & - & - & - & NP & - & - & - \\
\hline $\begin{array}{r}\text { MPM-PI- } \\
19277\end{array}$ & $X$ & $X$ & - & $X$ & NP & NP & NP & - & NP & - & - & - & NP & - & - & - \\
\hline $\begin{array}{r}\text { MPM-PI- } \\
19278\end{array}$ & 43.6 & 43 & 0.99 & NP & 28.8 & 5.5 & 24.6 & PP & 19.8 & PP & II & 81.2 & $\mathrm{X}$ & - & - & 91.7 \\
\hline $\begin{array}{r}\text { MPM-PI- } \\
19279\end{array}$ & $X$ & $X$ & - & NP & $X$ & NP & $C^{*}$ & NP & PP & NP & - & - & PP & NP & - & - \\
\hline $\begin{array}{c}\text { MPM-PI- } \\
19280\end{array}$ & $X$ & $X$ & - & $X$ & NP & NP & NP & - & NP & - & - & - & NP & - & - & - \\
\hline
\end{tabular}

Table 2

Descriptive statistics of quantitative characters of collected specimens.

\begin{tabular}{|c|c|c|c|c|c|c|}
\hline Character & Min. & Max. & $\mathrm{x}^{-}$ & SD & $\mathrm{CV}$ & $\mathrm{N}$ \\
\hline Test length & 38.9 & 53.3 & 45.6 & 3.66 & 0.08 & 32 \\
\hline Test width & 38.7 & 50.2 & 44.1 & 2.68 & 0.06 & 32 \\
\hline Test width as test length & 0.9 & 1.05 & 0.97 & 0.03 & 0.04 & 32 \\
\hline Test height & 15.8 & 22.2 & 19.5 & 1.94 & 0.09 & 17 \\
\hline $\begin{array}{l}\text { Distance from apical disc to } \\
\text { anterior margin (mm) }\end{array}$ & 24.1 & 35.1 & 29.0 & 2.63 & 0.09 & 28 \\
\hline $\begin{array}{l}\text { Distance from apical disc to } \\
\text { anterior margin (\%) }\end{array}$ & 63.2 & 76.1 & 54.6 & 5.39 & 0.09 & 26 \\
\hline Length of ambulacrum III & 22.7 & 34.0 & 26.5 & 2.57 & 0.09 & 29 \\
\hline Pore count on ambulacrum III & 39.0 & 42.0 & 40.2 & 1.59 & 0.03 & 5 \\
\hline Length of anterior paired petals & 18.5 & 25.7 & 21.2 & 1.70 & 0.08 & 28 \\
\hline $\begin{array}{l}\text { Length of anterior paired petals as } \\
\text { test length }(\%)\end{array}$ & 40.3 & 53.2 & 45.6 & 2.97 & 0.07 & 24 \\
\hline Pore count on anterior paired petals & 30 & 36 & 33.5 & 1.85 & 0.06 & 8 \\
\hline $\begin{array}{l}\text { Angle between anterior paired } \\
\text { petals }\end{array}$ & 75.2 & 86.2 & 81.4 & 3.18 & 0.04 & 20 \\
\hline Length of posterior paired petals & 6.3 & 12.9 & 9.4 & 1.28 & 0.13 & 21 \\
\hline $\begin{array}{l}\text { Length of posterior paired petals as } \\
\text { test length }(\%)\end{array}$ & 14.5 & 24.2 & 20.1 & 2.03 & 0.10 & 21 \\
\hline $\begin{array}{l}\text { Pore count on posterior paired } \\
\text { petals }\end{array}$ & 16 & 18 & 17.5 & 1.00 & 0.06 & 4 \\
\hline $\begin{array}{l}\text { Angle between posterior paired } \\
\text { petals }\end{array}$ & 71.1 & 97.4 & 86.6 & 6.14 & 0.08 & 18 \\
\hline
\end{tabular}

Coolpix P6000 cameras. Maps and diagrams were prepared using Inkscape 0.92 .3 (stable version) and Corel Draw X8. Identification and systematics follow Villier et al. (2004), Stockley et al. (2005), Kroh and Smith (2010), and Smith and Kroh (2011). The structure of the description follows Kier (1972). Specimens are housed in the Museo Regional Provincial Padre Jesús Molina (Río Gallegos, Santa Cruz Province, Argentina) under the registration numbers MPM-PI-19236 to MPM-PI-19280.

\section{Results}

Sixty-five specimens were found in a single layer of the Monte León Formation, all but three loose specimens were preserved with their oral side facing downwards and 50 tests had patches of spines still attached on both the oral and aboral surfaces. Spines were preserved mainly in ambulacra III and IV on the aboral surface and on the oral surface near the anterior margin and the periproct. Those associated to the unpaired ambulacrum are fine, long, and sharp, with widened bases. All specimens are similar in size and shape but vary in preservation quality within the same bedding plane, depending on their exposure to weathering and grain size of the adhering sediment.

Those specimens that were still covered by a fine-grained sediment coat were preserved as almost complete tests retaining parts of the spine cover. On the contrary, those that had been exposed for a prolonged time

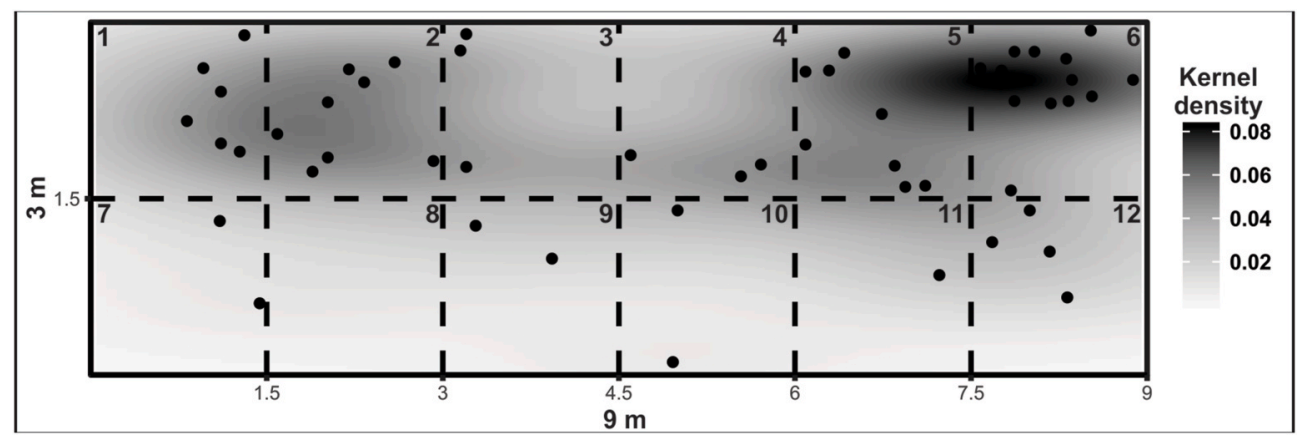

Fig. 4. Kernel density plot for the studied layer. Kernel density values were calculated with R. 

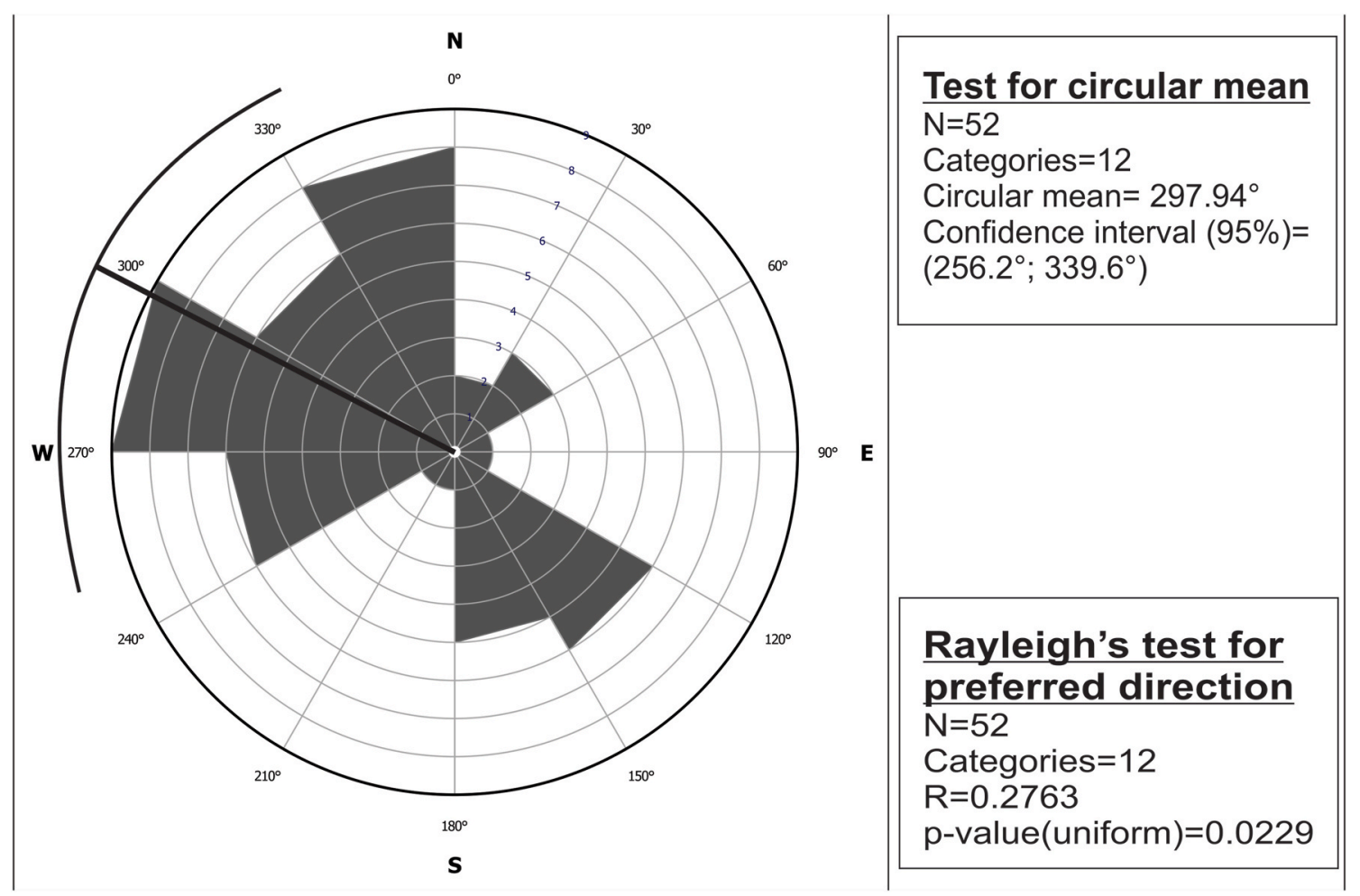

Fig. 5. Rose diagram for echinoid test orientation on the site's surface, circular mean value and Rayleigh Test results for $\mathrm{N}=12$.
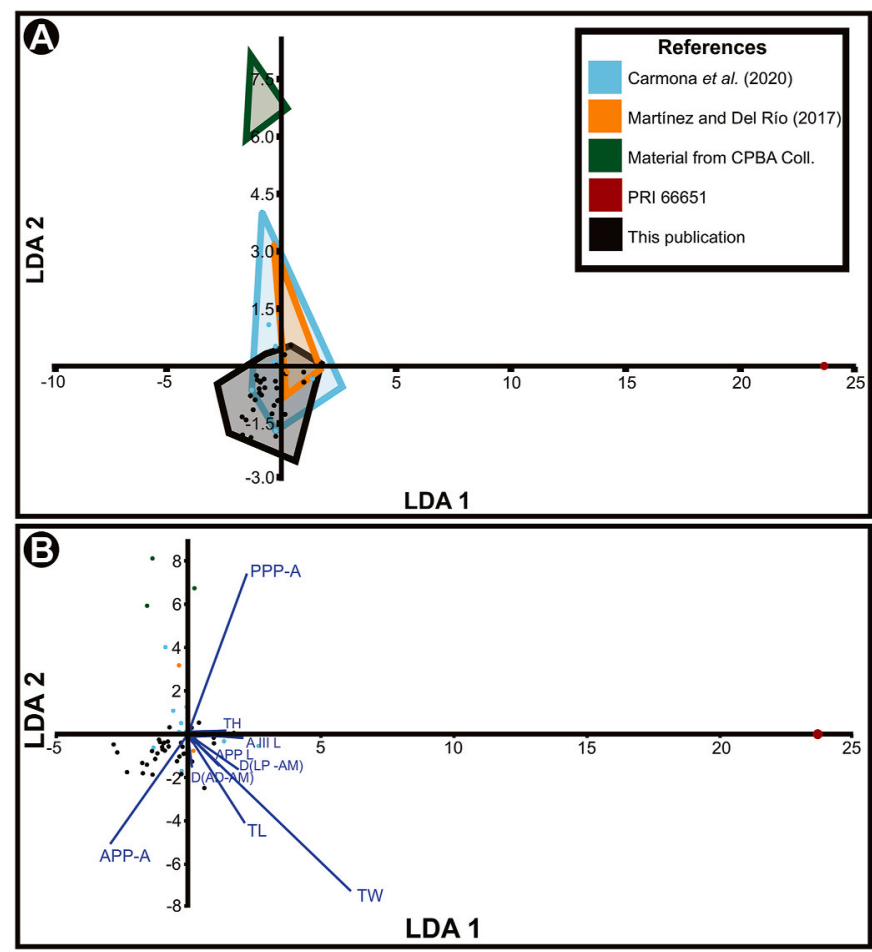

Fig. 6. Results of the Linear Discriminant Analysis (LDA). A: score plot, the colored polygons represent each analyzed specimen group. The points shared by two or more polygons represent specimens that have not significant differences between the groups and could be assigned to more than one analized category. B: Bi-Plot. Vectors show the individual contribution of each morphological measurement on the overall variance between groups. prior to collection were less well preserved, showing loss of plates, erosion, and fragmentation.

The specimens showed moderate to high levels of recrystallization, cementation, and compaction. Almost all spatangoids had manganese oxide attached as dendrites and botryoidal clusters, often causing replacement of the coronal plates. Seven specimens were almost completely replaced by manganese oxide. In other cases, a fine coat of diagenetic syntaxial rim cement covered the test, hiding details such as the tuberculation, on both oral and aboral surfaces (Fig. 7, J-L).

Approximately $50 \%$ of the specimens showed signs of compaction (flattening, fractures, collapsed aboral surface, plate displacements). The sediment infilling the corona of the spatangoid was identical to the embedding substrate.

Descriptive statistics of quantitative characters of the echinoid specimens are provided in Table 2. The Clark Evans analysis for spatial distribution showed that echinoids were clustered within the layer $(\mathrm{R}=$ $0.86949 ; \mathrm{p}$-value $=0.014 ; \mathrm{n}=52$ ). The Poisson test by quadrats showed the same pattern $\left(\chi^{2}=19.819\right.$; $\mathrm{p}$-value $\left.=0.031 ; \mathrm{v}=10\right)$. The highest densities were observed in quadrats 6 (5.78 individuals $\left./ \mathrm{m}^{2}\right), 2$, and 5 (3.56 ind. $/ \mathrm{m}^{2}$ ), while the density of the whole area was 1.96 individuals $/ \mathrm{m}^{2}$. Density plot shows that relative Kernel density values are higher in this area (Fig. 4). On the other hand, the statistical analysis for spatial orientation established a preferential orientation for the intervals $270^{\circ}-300^{\circ}$ and $330^{\circ}-360^{\circ}$ (Rayleigh test for preferred direction, $\mathrm{R}=$ 0.2763 , p-value $=0.0229$, see Fig. 5).

The LDA showed that based on the morphometric measurements there are no statistically significant differences between the specimens studied by Martínez and del Río (2017), Carmona et al. (2020), and those studied herein, while it clearly differentiated the specimens housed in the Palaeontological Research Institution and Universidad de Buenos Aires (Fig. 6A and B). The two principal eigenvalues explain $92.52 \%$ of the morphometric variability. The confusion matrix showed that $89.19 \%$ of the specimens were correctly classified within the groups. The 10.81 remaining percentage is represented by the specimens PRI 66651, and CPBA 6477, 6478 and 17,352 (Fig. 6C and D).

The thin sections revealed that cementation occurred on both 

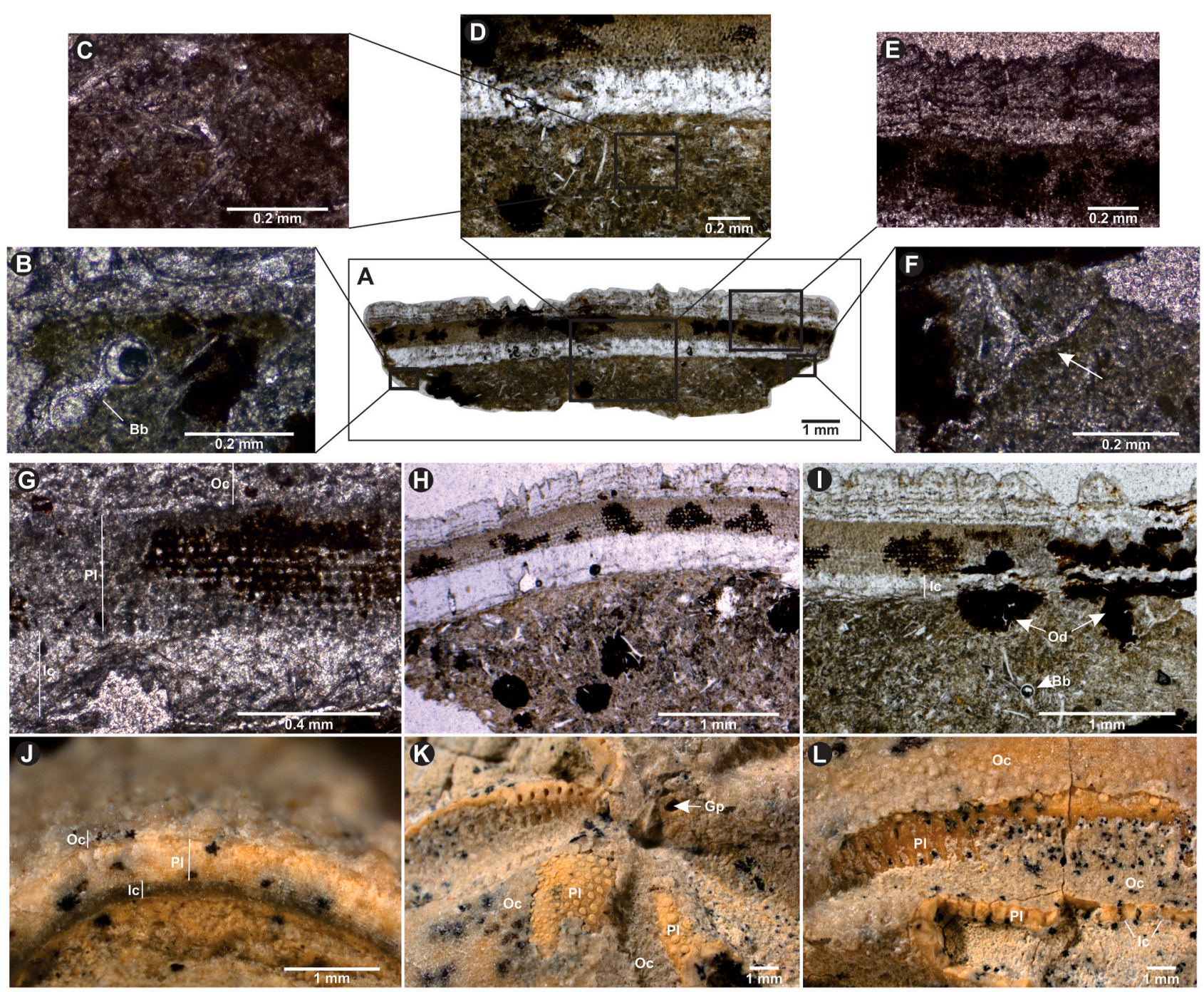

Fig. 7. Brisaster aff. iheringi A-F: MPM-PI-19254, thin section of a plate from supraambital interambulacrum 2. A: general view. B: sedimentary infilling on left margin of section, illustrating ash bubble. C: trigonal ash fragments in sediment. D: massive inner cement lining and sedimentary infill of echinoid test with oxides and volcanic ash. E: outer cement layer under polarized light and crossed nicols, showing that cement crystal extinction is parallel to plate axis. F: deformed trigonal ash fragment. G-I: another thin section of a supraambital plate from interambulacrum 2. G: general view of stereom structure and cement lining. H: botryoidal oxide structures (black spots) within volcanic ash inside echinoid test. I: destruction of stereom and cement by oxide formation. J: MPM-PI-19254, transverse view of supraambital plate in IA2, showing inner and outer cement layer. K: MPM-PI-19242a binocular microscope view of apical disc and adjacent parts of petals showing outer cement (Oc), as well as exposed areas not covered by cement and still preserving tuberculation details (Pl), as well as gonopore (Gp). L: MPM-PI-19242a binocular microscope view of petal 4, showing outer cement layer (Oc) covering all of the surface except the petals (Pl).

internal and external surfaces of the test. Cementation follows - at least externally - a syntaxial pattern and the external cement coat shows high levels of alteration and replacement by other minerals. Manganese and iron oxides were present inside the plate and between the cement crystals (Fig. 7, A, E-I). Nevertheless, the coronal plates are very well preserved and features of the stereom could be observed (Fig. 7, G-I). The sediment infilling the spatangoid tests, as well as the embedding substrate, contained a huge amount of volcanic ash, volcanic shards, and rarely, sponge spicules (Fig. 7, A-I).

Sedimentological samples showed a strong chemical reaction when exposed to hydrogen peroxide. The highest amount of sediment was retained in the $250 \mu \mathrm{m}$ sieve. At this size, presence of volcanic shard was low $(<20 \%)$, the sediment was composed mainly of lithic grains $(\sim 40 \%)$, iron and manganese oxide botryoidal structures, and echinoid spines $(\sim 20 \%)$. The smaller sediment sizes increased significantly in their volcanic content, being near to $60 \%$ in the sediment retained in the $63 \mu \mathrm{m}$ sieve.

Volcanic shards appear as triangular and acute structures, as well as glass fragments and bubbles. In the finer grain size fraction of the sediment, the content of botryoidal manganese oxide and echinoid spines decreased, being replaced by quartz and lithic grains. Quartz was found as small but distinctly grouped crystals.

Systematic Paleontology.

Class Echinoidea Leske, 1778.

Order Spatangoida L. Agassiz (1840).

Suborder Paleopneustina Markov and Solovjev, 2001.

Family Schizasteridae Lambert, 1905.

Genus Brisaster Gray, 1855.

Brisaster aff. iheringi De Loriol, 1902.

Figs. 8-11.

Type material of Brisaster iheringi De Loriol, 1902. - When De Loriol (1902) described the species, he did not designate a holotype. All specimens appear to have been poorly preserved and even the specimen figured by de Loriol (possibly MHNG GEPI 28012; see Martínez and del Río, 2017: Fig. 4D) was an internal mould. Other potential type material is missing in the collections (Martínez and del Río, 2017), except for two 

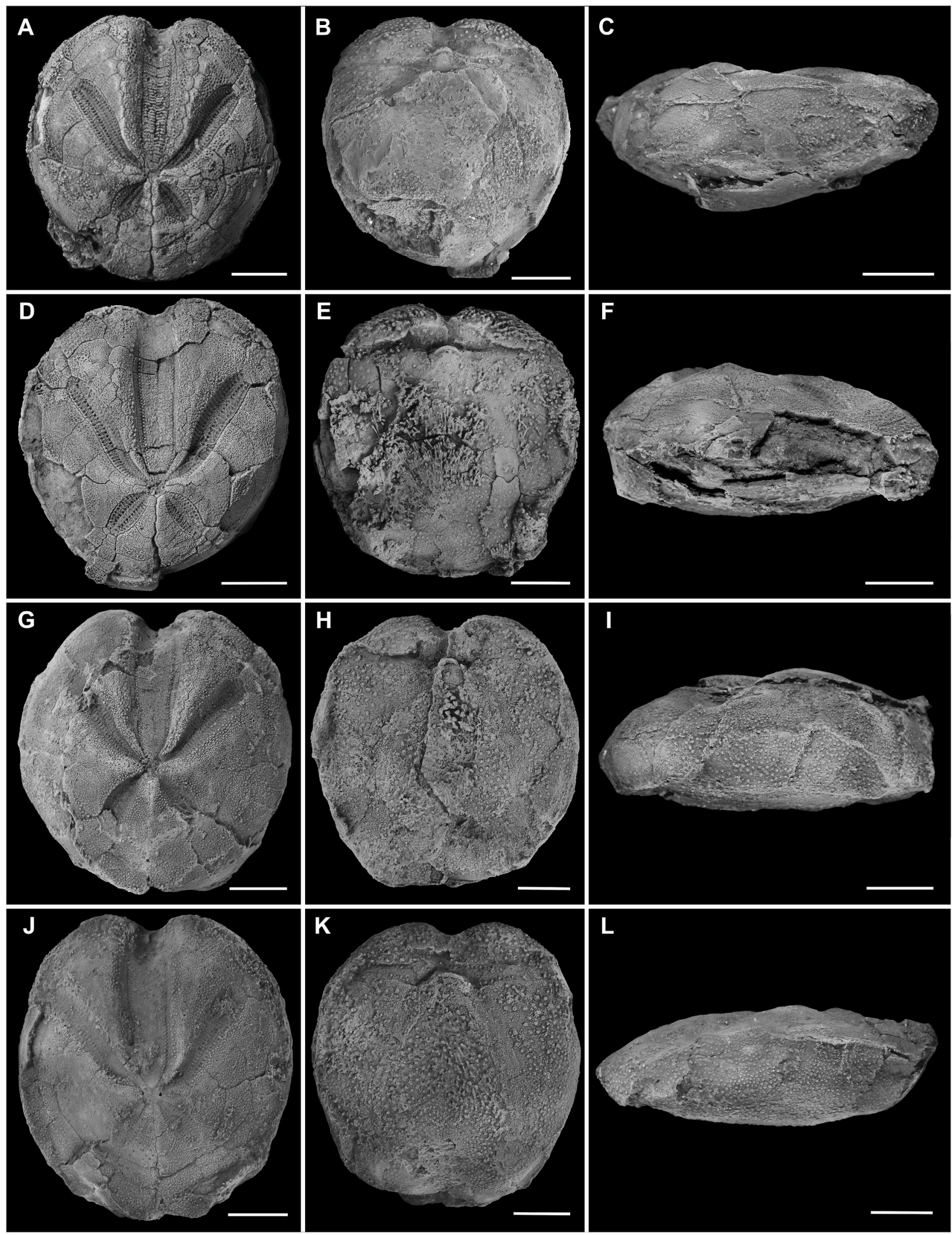

Fig. 8. Brisaster aff. iheringi: aboral, oral, and lateral views of tests. A-C: MPM-PI- 19274, A: aboral, B: oral, C: lateral; D-F: MPM-PI-19251, D: aboral, E: oral, F: lateral; G-I: MPM-PI-19265, G: aboral, H: oral, I: lateral; J-L: MPM-PI-19247, J: aboral, K: oral, L: lateral. Scale bars equal $1 \mathrm{~cm}$. 

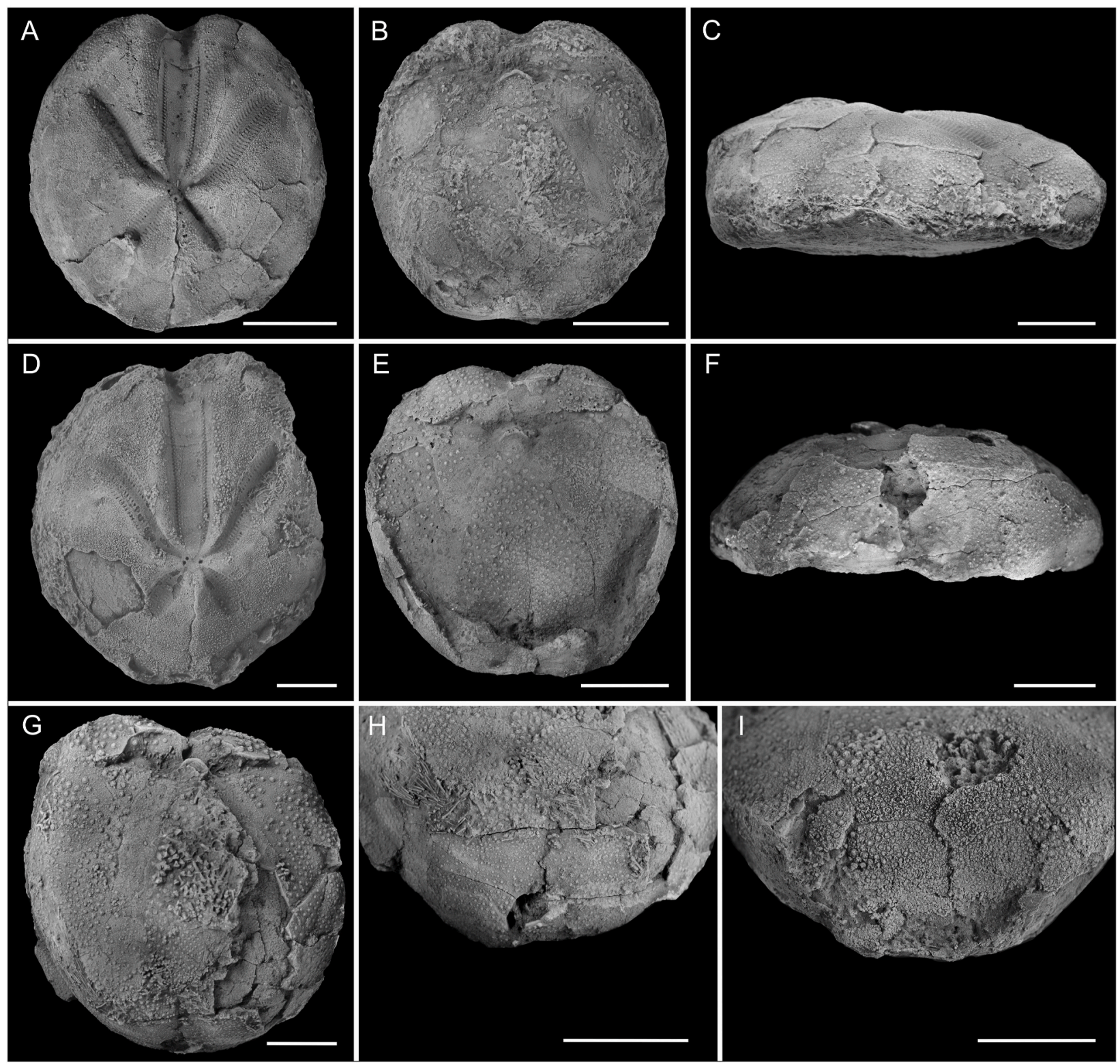

Fig. 9. Brisaster aff. iheringi: aboral, oral and lateral views of tests. A-C: MPM-PI- 19245, A: aboral, B, oral, C: lateral; D: MPM-PI-19264, aboral; E-F: MPM-PI-19246, E: oral, F: posterior; G-H: MPM-PI-19273, G: oral view, H: oblique view of subanal region, I: MPM-PI-19256, oblique view of subanal region without fascioles. Scale bars equal $1 \mathrm{~cm}$.

potential syntypes housed at the Museo Argentino de Ciencias Naturales "Bernardino Rivadavia" under the repository number MACN-Pi 4524 and Paleontological Research Institution under number PRI 66651, both of which are poorly preserved.

Diagnosis of Brisaster iheringi De Loriol, 1902.-A species of Brisaster with shallow frontal notch, test approximately as wide as long, very posterior apical disc (c. 68-75\% TL from anterior end), aboral interambulacra I and $\mathrm{V}$ raised, weakly developed crest near the apical disc, very short posterior paired petals (about 2-2.5 times shorter than anterior paired petals), and wide sternal plates (based on the redescription by Bernasconi, 1961 and Martínez and del Río, 2017).

Occurrence.-Single layer from Monte Leon Formation (early Miocene), GPS coordinates: $48.956^{\circ} \mathrm{S} ; 67.648^{\circ} \mathrm{W}, 40 \mathrm{~km}$ North of Puerto San Julián City, Santa Cruz Province, Argentina.

Description.-Test length (TL) 38.9-53.3 mm (mean = 45.5; SD = $3.66 ; \mathrm{CV}=0.08 ; \mathrm{N}=32$ ), width $0.90-1.05 \%$ TL (mean $=0.97 ; \mathrm{SD}=$ $0.04 ; \mathrm{CV}=0.04 ; \mathrm{N}=32$ ). Maximum width near center (mean $=44.1$; $\mathrm{SD}=2.68 ; \mathrm{CV}=0.06 ; \mathrm{N}=32$ ). Test rounded, slightly elongated along antero-posterior axis, moderately depressed in aboral surface (Fig. 8).

Test height 15.8-22.2 (mean =19.5; $\mathrm{SD}=1.94 ; \mathrm{CV}=0.09 ; \mathrm{N}=17$ ), highest at anterior interambulacra near the apical system. Posterior margin truncated (Fig. 8C, F, I, L; 9C). Apex displaced towards the posterior end of test, $24.1-35.1 \mathrm{~mm}$ from anterior margin (mean $=29.0$; $\mathrm{SD}=2.63 ; \mathrm{CV}=0.09 ; \mathrm{N}=28$ ), 54.59-76.09\% of TL (mean = 63.25; SD $=5.39, \mathrm{CV}=0.09 ; \mathrm{N}=26$ ). Apical system ethmolytic, with three circular gonopores (Fig. 10C and D; 11A-C) extending posteriorly; gonopore 2 absent.

Anterior unpaired ambulacrum (III) non-petaloid, wide and deeply excavated, forming notch at anterior margin (Fig. 8A, D, G; 10A-B). Walls on each side of aboral ambulacrum III vertical. Two rows of 39-42 pores pairs in each column ( mean $=40.2 ; \mathrm{SD}=1.09 ; \mathrm{CV}=0.03 ; \mathrm{N}=5$ ). Pores within each pair small, circular, separated from each other by a small, raised knob (Fig. 11D). Interporiferous zone wide (Fig. 10A and B). In many specimens, long, thin spines oriented towards the apical system were preserved in ambulacrum III and adjacent interambulacra (Fig. 11G). 

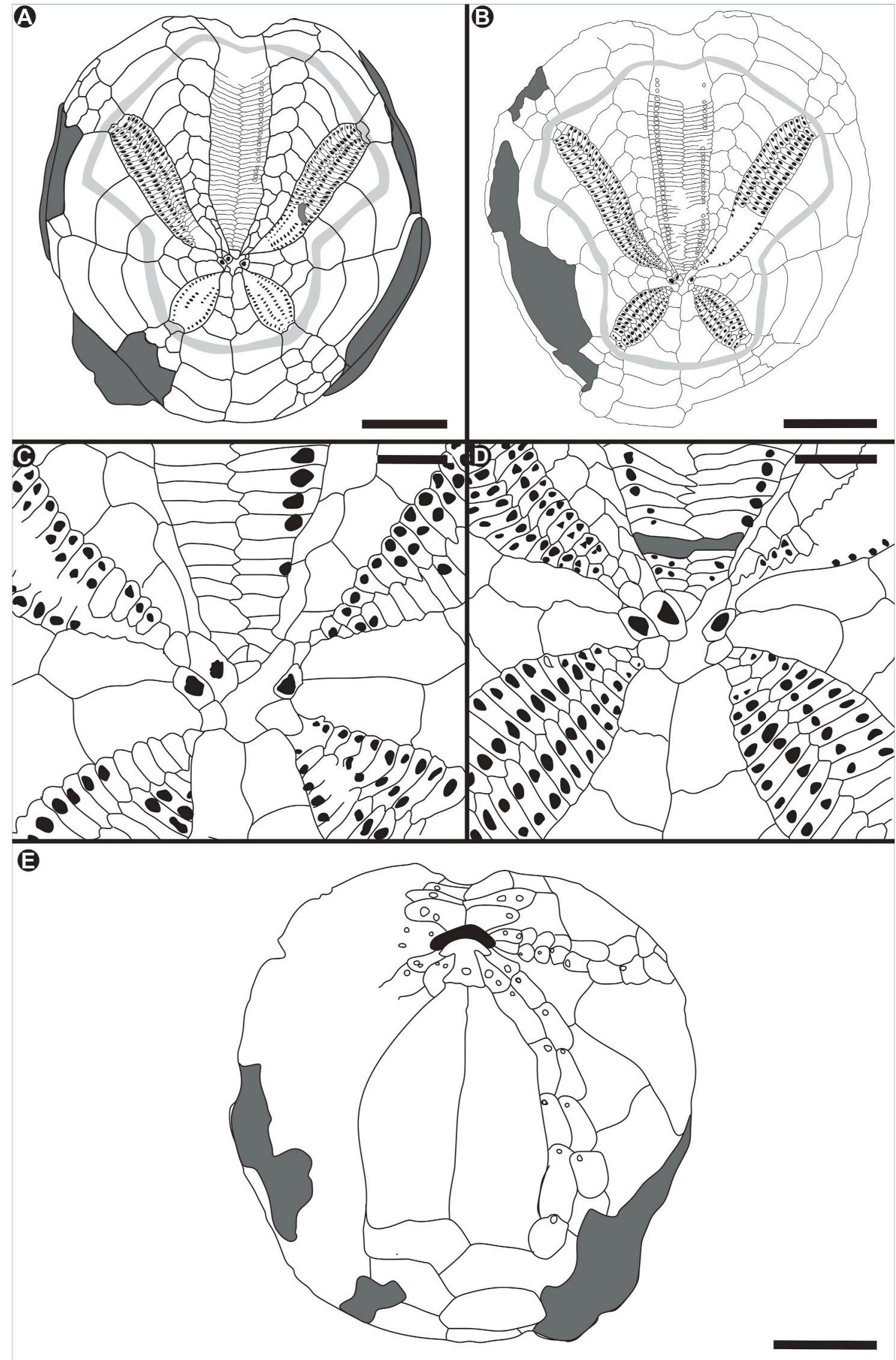

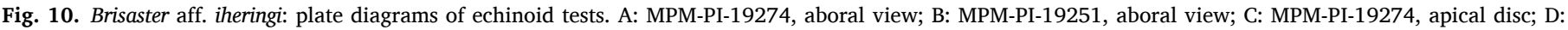

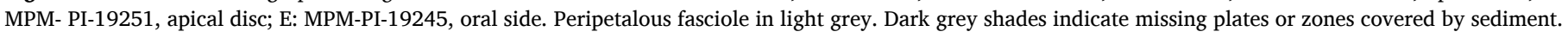



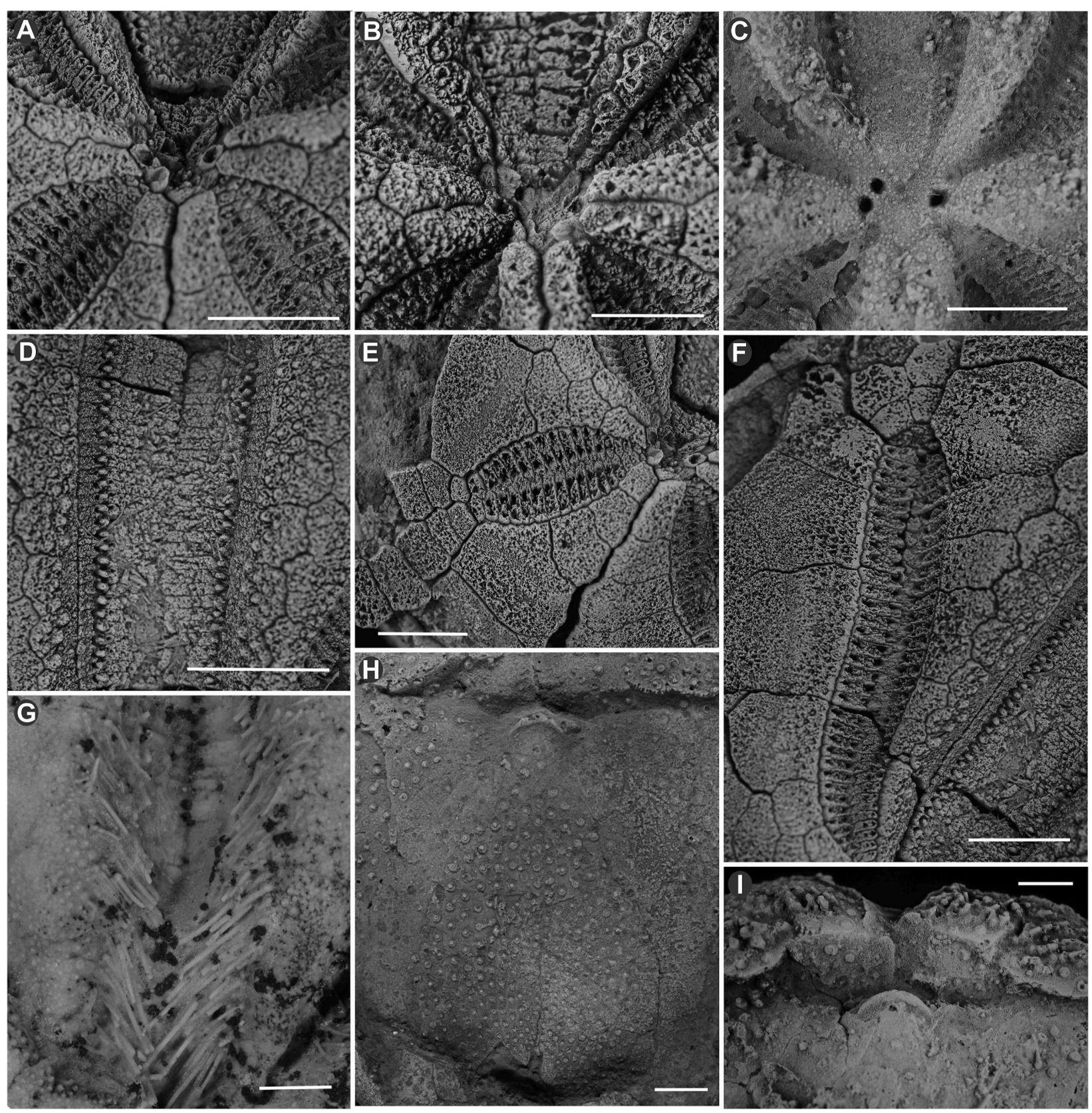

Fig. 11. Brisaster aff. iheringi: detailed pictures of key characters. A: apical disc of MPM-PI-19251; B: apical disc from MPM-PI-19274; C: apical disc of MPM- PI19264; D-F: MPM-PI-19251, D: ambulacrum III, E: petal V, F: petal IV; G: ambulacrum III of MPM-PI-19258 with spines attached in life position; H: MPM-PI19246, general view of sternal plates; I: MPM-PI-19274, detailed view of labral plate. Scale bars equal $0.4 \mathrm{~mm}$.

Anterior paired petals (II and IV) length 18.5-25.7 $\mathrm{mm}$ (mean = $21.2 ; \mathrm{SD}=1.70 ; \mathrm{CV}=0.08 ; \mathrm{N}=28$ ), $40.34-53.18 \%$ of $\mathrm{TL}$ (mean $=$ 45.62; $\mathrm{SD}=2.97 ; \mathrm{CV}=0.07 ; \mathrm{N}=24$ ), narrow and slightly curved toward lateral margin in anterior half (Fig. 11F). Two rows of pore pairs, subcircular to oval, bigger than pores of ambulacrum III (Fig. 9D; 11F); 32 to 38 pore pairs in each column (mean $=33.5$; $\mathrm{SD}=1.85$; $\mathrm{CV}=0.06$; $\mathrm{N}=8)$.

Interporiferous zone narrow, free of tubercles. Angle between anterior paired petals $75^{\circ}-86^{\circ}$ (mean $=81.4^{\circ} ; \mathrm{SD}=3.17 ; \mathrm{CV}=0.04 ; \mathrm{N}=$ 20).

Posterior paired petals (I and V) short, oval, and slightly sunken (Fig. 8A; 11E), 6.3-12.9 mm in length (mean = 9.4; $\mathrm{SD}=1.27$; $\mathrm{CV}=$ $0.13 ; \mathrm{N}=21$ ), $14.55-24.20 \%$ of TL (mean $=20.06$; $\mathrm{SD}=2.03$; $\mathrm{CV}=$ $0.10 ; \mathrm{N}=21$ ), diverging $71^{\circ}-97^{\circ}$ from each other (mean $=86.6$; $\mathrm{SD}=$ $6.14 ; \mathrm{CV}=0.07 ; \mathrm{N}=18$ ), $16-18$ pore pairs per column; interporiferous zone reaches almost width of single pore zone at its widest point and is free from tubercles (Fig. 11E). Aboral interambulacra I and V raised, forming weakly developed crest near the apical disc (Fig. 8D, G, J; 9A, D).

Peristome anterior, broader than long, slightly depressed, with projecting labrum (Fig. 8B, H, K; 9B, E; 11H-I). Labral plate enlarged, largely covering peristome in oral view. Peristomal margin of labrum located 5.1-11.7 mm from anterior margin (mean = 7.9; $\mathrm{SD}=1.85 ; \mathrm{CV}$ $=0.23 ; \mathrm{N}=22$ ); labrum mushroom-shaped, slightly longer than wide, with distinct rim along peristomial edge (Fig. 10E-G; 11H-I). Periproct subcircular to oval, longer than wide, collapsed or poorly preserved in most specimens (Fig. 9F-H).

Peripetalous fasciole well developed, differentiated as narrow band of small tubercles (Fig. 10A and B), indented in interambulacral column $1 \mathrm{~b}$, fasciole pattern $(4,4: 5 \rightarrow 7,6: 9($ ?); following the annotation by 


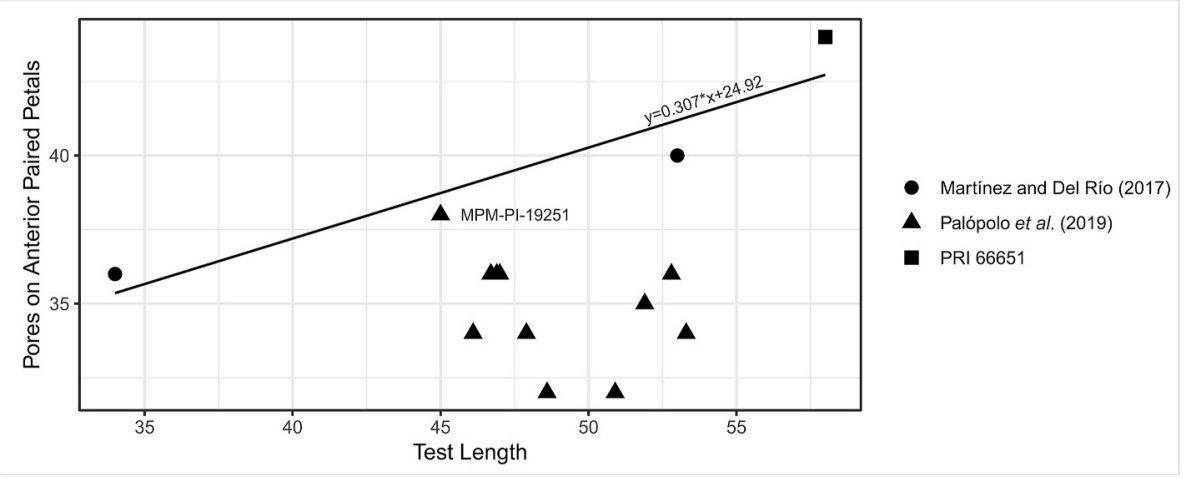

Fig. 12. Dispersion diagram of test length and number of pores on anterior paired petals, using data from the Monte León Formation population (this study), Martínez and del Río (2017), and one specimen from the Paleontological Research Institution, Ithaca, USA (PRI 66651). Regression line was calculated using MPM-PI-19251 and specimens from Martínez and del Río (2017).

Smith and Stockley, 2005). Latero-anal fasciole not present in examined specimens (Fig. 8I, L; 9G-I).

Materials. - Forty-five nearly complete specimens examined (MPMPI-19236 to MPM-PI-19280). Twenty-two of them were used for description (MPM-PI-19237, MPM-PI-19240-42a, MPM-PI-19243, MPM-PI-19245-47, MPM-PI-19249-51, MPM- PI-19254, MPM-PI19256, MPM-PI-19258-61, MPM-PI-19264-65, MPM-PI-19267, MPMPI-19274, MPM-PI-19278).

Remarks. - The specimens described as Brisaster iheringi by Martínez and del Río (2017) and Carmona et al. (2020), from the Chenque Formation, differ by their wider sternal plates, much more posteriorly placed apical system, much shorter posterior petals, wider ambulacrum III, and lower number of pores (Fig. 12). However, discriminant analysis including the specimens of Martínez and del Río (2017), Carmona et al. (2020) and those studied herein shows no significant differences among analyzed morphometric measurements. Yet, further measurements and characters not available now on all studied specimens, and inclusion of a higher number of specimens in a new matrix, are necessary to fully confirm taxonomic identity. This said, the studied specimens clearly belong to the genus Brisaster, based on their ethmolythic apical system with three gonopores, lack of a sharp ridge in aboral interambulacrum 5, wide sternal plates, and absence of lateroanal fascioles in adults (Gibbs, 1963; Smith and Kroh, 2011). Within the studied specimens, only specimen MPM-PI-19251 (Fig. 9D) approaches the morphology of the material studied by Martínez and del Río (2017), since it has shorter posterior paired petals with fewer pores than the remainder of the material studied here. Still, the Brisaster material from the Monte León Formation is closer to $B$. iheringi than to other well-known species of Brisaster. While it possibly represents a new species, it is at present premature to establish it as such, since many of the fossil species in this group are incompletely known. This contrasts with the modern species of Brisaster which were revised by Hood and Mooi (1998) and for which a phylogenetic framework was presented.

\section{Discussion}

Spatangoids are a group of irregular echinoids with thin-walled tests which are prone to fragmentation and disarticulation when subject to reworking or winnowing processes (Mancosu et al., 2015). Appendages such as spines and pedicellariae are typically lost within the first week after death, and transport induces rapid fragmentation of specimens (Brett et al., 1997).

On the other hand, spatangoids are burrowing deposit-feeder echinoids, and this mode of life allows them to be preserved as almost complete tests when buried quickly (Kier, 1977; Néraudeau, 1991; Mancosu and Nebelsick, 2017) in anoxic or poorly oxygenated environments (Mancosu et al., 2015). The deposition of large quantities of sediment in short periods of time has severe effects on echinoid populations (Smith, 1984). For example, Schäfer (1972) stated that in Echinocardium, a rapid deposition of a 30-cm-thick layer of fine-grained sand is sufficient to prevent escape of the trapped echinoids.

The fossils studied herein are almost complete and moderately to well-preserved. All the echinoids sampled from the Monte León Formation belong to the same species and were found in life position, filled by the same surrounding sediment, with spines attached and without signals of reworking, suggesting the spatangoid assemblage was buried alive. The layer can thus be classified as a monotypic autochthonous concentration (Kidwell et al., 1986). This kind of assemblage is common in the marine Miocene of Patagonia (del Río et al., 2001; Casadio et al., 2005; Caviglia et al., 2007; Crawford et al., 2008; Martínez and del Río, 2008; 2017; Martínez et al., 2010; Maguire et al., 2016; Carmona et al., 2020), mainly in rocks with high volcanic content.

The presence of manganese and iron oxides, both in dendrites and botryoidal habit, suggests high content of organic matter within a suboxic to anoxic environment (Schulz et al., 1994) and is coincident with the strong reaction of the sediment when exposed to hydrogen peroxide. Recrystallization, cementation, and fragmentation by diagenetic processes affecting fossils can be attributed to early stages in the fossilization process (Maguire et al., 2016). Recrystallization did not obliterate the stereom microstructure. Syntaxial cementation, in contrast, obscures morphological features, as it is common particularly in medium to coarse grained siliciclastic sediments and the result of high sediment porosity and non-marine cementation during the first diagenetic stages (Kroh and Nebelsick, 2010; and references therein). The iron-oxide between cement crystals could be associated to bacterial activity in early fossilization stages, as stated by Maguire et al. (2016). The presence of volcanic glass in the early Miocene of Patagonia has been widely reported and has been associated with very well preserved infaunal taxa (Bertels, 1970; Di Paola and Marchese, 1973; Riggi, 1978; Casadio et al., 2005; Crawford et al., 2008, Cuitiño, 2011; Parras et al., 2012; Maguire et al., 2016; Cuitiño et al., 2018). Also, high content of volcanic ash has been considered an important factor in fossil preservation, together with high sedimentation rates and poor sediment reworking (Rodríguez et al., 2008; Cuitiño, 2011; Maguire et al., 2016). Carmona et al. (2020) reported several echinoid tests of Brisaster iheringi with spines preserved and associated to their trace fossils (Scolicia isp.). The depositional environment was interpreted as an intermittent storm-affected lower shoreface (Carmona et al., 2020). The specimens studied therein were almost identical to those reported here, with the same measurements and similar structures. Both specimen clusters (from the Monte León and Chenque formations) also had spines attached in specific positions, showing that echinoderms were most likely killed by a high sedimentation rate which prevented them from escaping.

In the case of the Monte León Formation, echinoids colonized a distal 


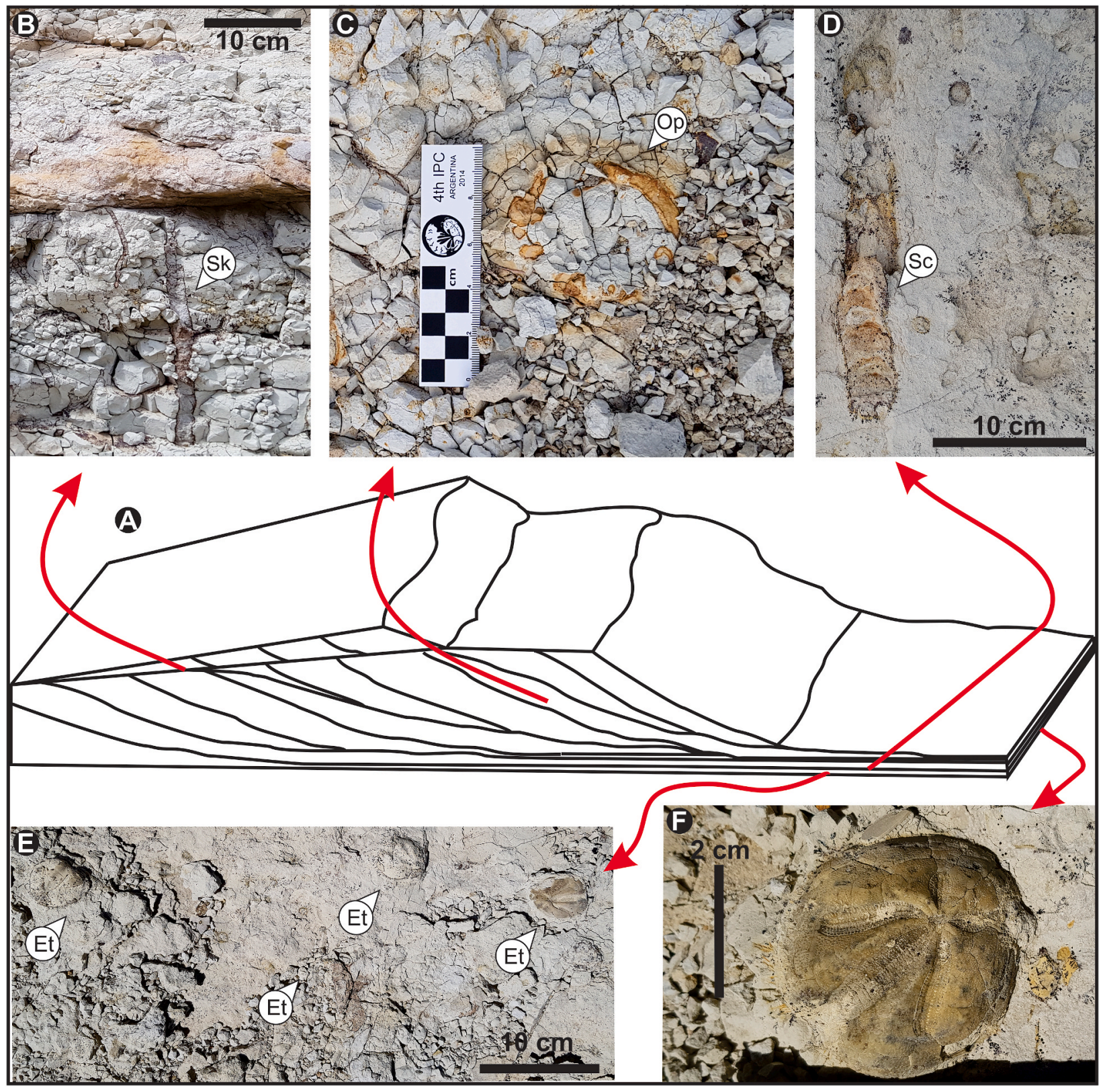

Fig. 13. Interpretation of depositional environment and position of the fossil layer. A: general diagram of depositional environment; B: Skolithos isp. (Sk); C: Ophiomorpha isp. (Op); D: Scolicia isp. (Sc); E: echinoid tests (Et) preserved in life position, in quadrat 6; F: detailed view of an echinoid test preserved in life position within the layer (MPM-PI- 19274).

part of the subtidal habitat dominated by large-scale migrant bedforms (Fig. 13), in a more dynamic environment than the one recorded at Playa Las Cuevas. During the dormant period, this setting was characterized by low energy and low sedimentation rates, allowing colonization by several groups of infaunal organisms. When the sediment migration was reactivated, a high sedimentary influx trapped the infauna, which prevented them from escaping. The bioturbation observed in the bottomset deposits suggests that the colonization window was relatively long.

According to Schinner (1993), modern spatangoids tend to excavate along the redox potential discontinuity layer (RPD). If burial of the community studied herein during an episodic event is assumed, the RPD layer should have quickly re-established higher up in the sediment layers, leaving the organisms in the more anoxic sediments. This situation, together with the thick layer of sediment deposited, could have delayed organic decay, favoring preservation of the articulated spines.

The fossil layer studied herein shows many similarities with other
Miocene spatangoid-dominated assemblages worldwide (i.e.: complete preservation of spatangoid tests within a single bed, with spines in life position, sometimes associated with their traces, inhabiting low-energy environments and buried by high sedimentary influx), as reported by Néraudeau et al. (2001), Radwañski and Wysocka (2001), Kroh and Nebelsick (2003), Bajo and Borghi (2009), Stara et al. (2012), Mancosu et al. (2015), and Mancosu and Nebelsick (2016; 2017).

\section{Authorship statement}

E.E. Palópolo: Conception and design of study, acquisition of data, analysis and/or interpretation of data, Drafting the manuscript, Approval of the version of the manuscript to be published (the names of all authors must be listed). A. Kroh: Conception and design of study, acquisition of data, analysis and/or interpretation of data, Drafting the manuscript, revising the manuscript critically for important intellectual 
content, Approval of the version of the manuscript to be published (the names of all authors must be listed). M. Harzhauser: analysis and/or interpretation of data, revising the manuscript critically for important intellectual content, Approval of the version of the manuscript to be published (the names of all authors must be listed). M. Griffin: Conception and design of study, acquisition of data, Drafting the manuscript, revising the manuscript critically for important intellectual content, Approval of the version of the manuscript to be published (the names of all authors must be listed). S. Casadio: Conception and design of study, acquisition of data, analysis and/or interpretation of data, Drafting the manuscript, revising the manuscript critically for important intellectual content, Approval of the version of the manuscript to be published (the names of all authors must be listed). N. Carmona: acquisition of data, Drafting the manuscript, revising the manuscript critically for important intellectual content, Approval of the version of the manuscript to be published (the names of all authors must be listed).

\section{Declaration of competing interest}

The authors declare that they have no known competing financial interests or personal relationships that could have appeared to influence the work reported in this paper.

\section{Acknowledgements}

This research was supported by a PhD scholarship given by CONICET to Evangelina Palópolo, and an Ernst Mach Worldwide 2018 Scholarship given to E.P. by the Austrian Agency for International Cooperation in Education and Research (OeAD-GmbH), and financed by Austrian Federal Ministry of Education, Science and Research. Reference number: ICM-2018-10045. Beca interna doctoral 2015, CONICET (Consejo Nacional de Investigaciones Científicas y Técnicas), Argentina. Resolución $\mathrm{N}^{\circ}$ 4868. Temporal fossil export was authorized by Gobierno de la Provincia de Santa Cruz, Museo Argentino de Ciencias Naturales (IF2018-58231802-APN-MACN\#CONICET) and AFIP (Subrégimen de exportación temporaria sin modificación 18/073/ET2/000311/V).

\section{References}

Agassiz, L., 1840. Catalogus Systematicus Ectyporum Echinodermatum Fossilium. Musei Neocomensis, vol. 20. Apud O. Petitpierre, p. 22 pl.).

Bajo, I., Borghi, E., 2009. Tripneustes gahardensis (Echinoidea) en el Mioceno de la Cuenca del Guadalquivir. Batalleria 14, 11-20.

Belaústegui, Z., Muñiz, F., Nebelsick, J.H., Domènech, R., Martinell, J., 2017. Echinoderm ichnology: bioturbation, bioerosion and related processes. J. Paleontol. 91 (4), 643-661.

Bernasconi, I., 1961. Equinoideos fósiles de la colección del Museo Argentino de Ciencias Naturales. Physis 21 (61), 137-176.

Bertels, A., 1970. Sobre el "Piso Patagoniano" y la representación de la época del Oligoceno en Patagonia Austral, República Argentina. Rev. Asoc. Geol. Argent. 25 (4), 496-501.

Brett, C.E., Moffat, H.A., Taylor, W.L., 1997. Echinoderm taphonomy, taphofacies, and Lagerstätten. Paleontol. Soc. Pap. 3, 147-190.

Carmona, N.B., Mángano, M.G., Buatois, L.A., Bromley, R.G., Ponce, J.J., Asgaard, U., Bellosi, E., 2020. Scolicia and its producer in shallow-marine deposits of the Miocene Chenque Formation (Patagonia, Argentina): functional morphology and implications for understanding burrowing behavior. Ichnos. https://doi.org/10.1080/ 10420940.2020.1744589.

Casadio, S., Feldmann, R.M., Parras, A., Schweitzer, C.E., 2005. Miocene fossil decapoda (crustacea, Brachyura) from Patagonia, Argentina, and their paleoecological setting. Ann. Carnegie Mus. 74, 151-188.

Casadio, S., Griffin, M., 2009. Sedimentology and paleontology of a Miocene marine succession first noticed by Darwin at Puerto Deseado (Port desire). Rev. Asoc. Geol. Argent. 64, 83-89.

Caviglia, S.E., Martínez, S., del Río, C.J., 2007. A new early Miocene species of ophiocrossota (ophiuroidea) from southern Patagonia, Argentina. Neues Jahrbuch Geol. Palaontol. Abhand. 245 (2), 147-152.

Crawford, R.S., Casadío, S., Feldmann, R.M., Griffin, M., Parras, A., Schweitzer, C.E. 2008. Mass mortality of fossils decapods within the Monte León Formation (early Miocene), southern Argentina: victims of andean volcanism. Anals of Carnegie Museum 77 (2), 259-287.

Cuitiño, J.I., 2011. Registro sedimentológico e isotópico de paleoambientes marinos y transicionales en el Patagoniano (Mioceno) del Lago Argentino. PhD dissertation. Facultad de Ciencias Exactas y Naturales. Universidad de Buenos Aires), p. 264.
Cuitiño, J.I., Dozo, M.T., del Río, C.J., Buono, M.R., Palazzesi, L., Fuentes, S., Scasso, R. A., 2018. Miocene marine transgressions: paleoenvironments and Paleobiodiversity. In: Bouza, P., Bilmes, A. (Eds.), Late Cenozoic of Península Valdés, Patagonia, Argentina. Springer Earth System Sciences, pp. 47-84.

Darwin, C., 1846. Geological Observations on South America. Being the Third Part of the Geology of the Voyage of the Beagle, under the Command of Capt. Fitzroy, R. N. During the Years 1832 to 1836. Smith Elder and Co., London, p. 279pp.

De Gibert, J.M., Goldring, R., 2007. An ichnofabric approach to the depositional interpretation of the intensely burrowed Bateig Limestone, Miocene, SE Spain. Sediment. Geol. 194 (1-2), 1-16.

De Gibert, J.M., Goldring, R., 2008. Spatangoid-produced ichnofabrics (Bateig Limestone, Miocene, Spain) and the preservation of spatangoid trace fossils. Palaeogeogr. Palaeoclimatol. Palaeoecol. 270 (3-4), 299-310.

De Loriol, P., 1902. Notes pour servir a l'étude des échinodermes 2 (1), 52, 3 pl.

del Río, C.J., 2004. Tertiary marine molluscan assemblages of eastern Patagonia (Argentina): a biostratigraphic analysis. J. Paleontol. 78 (6), 1097-1122.

del Río, C.J., Martínez, S.A., Scasso, R.A., 2001. Nature and origin of spectacular marine Miocene shell beds of northeastern Patagonia (Argentina): paleoecological and bathymetric significance. Palaios 16, 3-25.

del Río, C.J., Martínez, S., Stilwell, J.D., Concheyro, A.G., 2007. Paleontology of the danian cerros bayos section (La Pampa Province, Argentina). Alcheringa 31, 241-269.

Desjardins, P.R., Buatois, L.A., Mangano, M.G., 2012. Tidal flats and subtidal sand bodies. In: Knaust, D., Bromley, R.G. (Eds.), Trace Fossils as Indicators of Sedimentary Environments, vol. 64. Developments of Sedimentology, pp. 529-561.

Di Paola, E.C., Marchese, H.G., 1973. Litoestratigrafía de la Formación Patagonia en el área tipo (Bajo de San Julián - desembocadura del río Santa Cruz), Provincia de Santa Cruz, República Argentina. Actas del V Congreso Geológico Argentino 3, 207-222.

Echevarría, A.E., 2002. Ostrácodos de la Formación Monte León (Oligoceno tardíoMioceno temprano) del noreste de Gobernador Gregores, Santa Cruz, Argentina. Ameghiniana 39 (4), 405-414.

Elattaar, A.A., 2018. A new species of hypselaster (Echinoidea, Spatangoida) from the middle eocene midawara formation of the eastern desert, Egypt. Swiss Journal of Palaeontology 137 (2), 379-387.

Gibbs, P.T., 1963. Functional Morphology and Ecology of the Spatangoid Genus Brisaster Gray. M.S. thesis. University of British Columbia.

Gray, J.E., 1855. An arrangement of the families of Echinida, with descriptions of some new genera and species. In: Proceedings of the Zoological Society, London, vol. 23, pp. 35-39.

Hammer, Ø., Harper, D.A., Ryan, P.D., 2001. PAST: Paleontological statistics software package for education and data analysis. art. 4 Palaeontol. Electron. 4 (1), 9, 178kb.

Holmes, F.C., 2014. A late Miocene record of the echinoid maretia (Echinoidea, Spatangoida) from victoria, Australia. Mem. Mus. Vic. 72, 63-72.

Hood, S., Mooi, R., 1998. Taxonomy and Phylogenetics of Extant Brisaster (Echinoidea: Spatangoida). Echinoderms, San Francisco, pp. 681-686.

Ihering, H.I. von, 1897. Os Molluscos dos terrenos terciarios da Patagonia. Rev. Mus. Paul. 2, 217-382.

Jesionek-Szymañska, W., 1987. Echinoids from the cape melville formation (lower Miocene) of king george island, west Antarctica. Palaeontol. Pol. 49, 163-168.

Khaksar, K., Moghadam, I.M., 2007. Paleontological study of the echinoderms in the qom formation (Central Iran). Earth Sci. Res. J. 11 (1), 57-79.

Kidwell, S.M., Fuersich, F.T., Aigner, T., 1986. Conceptual framework for the analysis and classification of fossil concentrations. Palaios 1, 228-238.

Kier, P.M., 1972. Tertiary and mesozoic echinoids of Saudi arabia. Smithsonian Contrib. Paleobiol. 10, 1-242.

Kier, P.M., 1977. The poor fossil record of the regular echinoid. Palaeobiology 3, $168-174$.

Kroh, A., 2007. Climate changes in the early to middle Miocene of the central Paratethys and the origin of its echinoderm fauna. Palaeogeogr. Palaeoclimatol. Palaeoecol. 253 (1-2), 169-207.

Kroh, A., 2010. Index of living and fossil echinoids 1971-2008. Annalen des Naturhistorischen Museums in Wien. Serie A für Mineralogie und Petrographie, Geologie und Paläontologie, Anthropologie und Prähistorie, pp. 195-469.

Kroh, A., Mooi, R., 2018. World Echinoidea database. Spatangoida. Accessed through: World Register of Marine Species at: http://www.marinespecies.org/aphia.php? $\mathrm{p}=$ taxdetailsandid=123106 on 2018-12-19.

Kroh, A., Nebelsick, J.H., 2003. Echinoid assemblages as a tool for palaeoenvironmental reconstruction-an example from the Early Miocene of Egypt. Palaeogeogr. Palaeoclimatol. Palaeoecol. 201 (1-2), 157-177.

Kroh, A., Nebelsick, J.H., 2010. Echinoderms and Oligo-Miocene carbonate systems: potential applications in sedimentology and environmental reconstruction. Int. Assoc. Sedimentol. Spec. Publ. 42, 201-228.

Kroh, A., Smith, A.B., 2010. The phylogeny and classification of post-Palaeozoic echinoids. J. Syst. Palaeontol. 8 (2), 147-212.

Lambert, J., 1905. Notes sur quelques Échinides éocéniques de l'Aude et de l'Hérault. In: L. Doncieux. Catalogue descriptif des fossiles nummulitiques de l'Aude et de l'Hérault. Première Partie. Montagne Noire et Minervois. Annales de l'Université de Lyon, Nouvelle Série, I. Sciences, Médecine, vol. 17, pp. 129-164.

Leske, N.G., 1778. Jacobi Theodori Klein naturalis dispositio echinodermatum. Accesserunt lucubratiuncula de aculeis echinorum marinorum et spicilegium de belemnitis. Edita et descriptionibus novisque inventis et synonymis auctorem aucta xxii, 278. Lipsiae (Officina Gleditschiana).

Maguire, E.P., Feldmann, R.M., Casadio, S., Schweitzer, C.E., 2016. Distal volcanic ash deposition as a cause for mass kills of marine invertebrates during the Miocene in Northern Patagonia, Argentina. Palaios 31 (12), 577-591. 
Malumián, N., Náñez, C., 2011. The late cretaceous-cenozoic transgressions in Patagonia and the fuegian andes: foraminifera, palaeoecology and palaeogeography. Biol. J. Linn. Soc. 103, 269-288.

Mancosu, A., Nebelsick, J.H., Kroh, A., Pillola, G.L., 2015. The origin of echinoid shell beds in siliciclastic shelf environments: three examples from the Miocene of Sardinia, Italy. Lethaia 48 (1), 83-99.

Mancosu, A., Nebelsick, J.H., 2016. Echinoid assemblages from the early Miocene of Funtanazza (Sardinia): a tool for reconstructing depositional environments along a shelf gradient. Palaeogeogr. Palaeoclimatol. Palaeoecol. 454, 139-160.

Mancosu, A., Nebelsick, J.H., 2017. Palaeoecology and taphonomy of spatangoiddominated echinoid assemblages: a case study from the Early-Middle Miocene of Sardinia, Italy. Palaeogeogr. Palaeoclimatol. Palaeoecol. 466, 334-352.

Markov, A.V., Solovjev, A.N., 2001. Echinoids of the family Paleopneustidae (Echinoidea, Spatangoida): morphology, taxonomy, phylogeny. Geos - Trudy Paleontologicheskogo Instituta, Rossiskaia Akademia Nauk 280, 1-108.

Martínez, S., del Río, C.J., 2008. A new, first fossil species of Ophioderma müller and troschel, 1842 (echinodermata: ophiuroidea) (late Miocene, Argentina). Zootaxa 1841 (1), 43-52.

Martínez, S., del Río, C.J., 2017. A supplementary description of brisaster iheringi (Spatangoida: Schizasteridae) from the Miocene of Patagonia Argentina. Rev. Biol. Trop. 65 (1-1), 137-146.

Martínez, S., del Río, C.J., Pérez, D., 2010. A brittle star bed from the Miocene of Patagonia, Argentina. Lethaia 43, 1-9.

Martínez, S., del Río, C.J., Concheyro, A., 2011. Danian (early Paleocene) echinoids from the Roca formation, northern Patagonia, Argentina. Neues Jahrbuch für Paläontologie und Geologie 261, 165-176.

Néraudeau, D., 1991. Lateral variations of size- frequency distribution in a fossil echinoid community and their palaeoecological significance. Lethaia 24 (3), 299-309.

Néraudeau, D., Goubert, E., Lacour, D., Rouchy, J.M., 2001. Changing biodiversity of Mediterranean irregular echinoids from the Messinian to the present-day. Palaeogeogr. Palaeoclimatol. Palaeoecol. 175 (1-4), 43-60.

Olivera, A.M., Parma, S.G., Zinsmeister, W.J., 1994. Peonza; new gastropod genus from the middle Tertiary of Patagonia and Chile. J. Paleontol. 68, 279-286.

Ortmann, A., 1902. Tertiary invertebrates. Reports of the Princeton Uniersity Expedition to Patagonia 4 (2), 45-332.

Panza, J.L.A., Irigoyen, M.V., Genini, A., 1994. Hoja geológica 4969-IV, Puerto san Julián. In: Programa Nacional de Cartas Geológicas de la República Argentina 1: 250.000. Provincia de Santa Cruz. Buenos Aires. Servicio Geológico Minero Argentino. Instituto de Geología y Recursos Minerales.

Parma, S.G., 2012. El género Brissopsis L. Agassiz, 1840 (Echinoidea: Spatangoida) en el Paleógeno y Neógeno de la República Argentina. Revue de Paléobiologie, v. spec. 11, 417-427.

Parma, S.G., Casadío, S., 2005. Upper cretaceous-Paleocene echinoids from northern Patagonia, Argentina. J. Paleontol. 79, 1072-1087.

Parras, A., Casadío, S., 2005. Stratigraphy, taphonomy and sequence stratigraphic significance of oyster-dominated concentrations from the San Julián Formation, Oligocene of Patagonia, Argentina. Palaeogeogr. Palaeoclimatol. Palaeoecol. 217, 47-66.

Parras, A., Casadío, S., 2006. The oyster Crassostrea? hatcheri (Ortmann, 1897), a physical ecosystem engineer from the upper Oligocene-lower Miocene of Patagonia, southern Argentina. Palaios 21, 168-186.

Parras, A., Griffin, M., 2009. Darwin's great Patagonian tertiary formation at the mouth of the río Santa Cruz: a reappraisal. In: Aguirre-Urreta, B., Griffin, M., Ramos, V.A. (Eds.), Darwin in Argentina. Revista de la Asociación Geológica Argentina, 64(1), pp. 70-82.
Parras, A., Dix, G.R., Griffin, M., 2012. Sr-isotope chronostratigraphy of Paleogene-neogene marine deposits: austral basin, southern Patagonia (Argentina). J. S. Am. Earth Sci. 37, 122-135.

Pérez López, C., 2004. Técnicas de análisis multivariado de datos. Aplicaciones con SPSS $®$. Pearson Educación S.A., Madrid, España, p. 672pp.

Pineda-Salgado, G., Parras, A., Griffin, M., 2018. Sclerobionts on biogenic substrates from the Monte León Formation (lower Miocene) in Santa Cruz Province, Argentina: taphonomic and paleoenvironmental considerations. Palaeogeogr. Palaeoclimatol. Palaeoecol. 511, 606-619.

Pollard, J.E., Goldring, R., Buck, S.G., 1993. Ichnofabrics containing Ophiomorpha: significance in shallow-water facies interpretation. Journal of the Geological Society of London 150, 149-164.

R Core Team, 2014. R: A Language and Environment for Statistical Computing. R Foundation for Statistical Computing, Vienna, Austria. http://www.R-project.org/. Radwañski, A., Wysocka, A., 2001. Mass aggregation of Middle Miocene spine-coated echinoids Echinocardium and their integrated eco-taphonomy. Acta Geol. Pol. 4, $295-316$.

Riggi, J.C., 1978. La importancia de los sedimentos piroclásticos y de la sílice biogenética en la estratigrafía de la Formación Patagonia. Rev. Asoc. Geol. Argent. 33 (2), $158-171$.

Rodríguez, P.E., Tauber, A.A., Krapovickas, J.M., 2008. Asociaciones tafonómicas y tasa sedimentaria en piroclastitas de la Formación Santa Cruz (Mioceno tempranomedio), Patagonia Austral. XII Reunión Argentina de Sedimentología, Buenos Aires, Actas, p. 154.

Schäfer, W., 1972. In: Oertel, I., Craig, Y. (Eds.), Ecology and Palaeoecology of Marine Environments. Translated from the German Edition (1962). University of Chicago Press, p. 568.

Schinner, G.O., 1993. Burrowing behavior, substratum preference, and distribution of Schizaster canaliferus (Echinoidea: Spatangoida) in the northern Adriatic Sea. Mar. Ecol. 14 (2), 129-145.

Schulz, H.D., Dahmke, A., Schinzel, U., Wallmann, K., Zabel, M., 1994. Early diagenetic processes, fluxes, and reaction rates in sediments of the South Atlantic. Geochem. Cosmochim. Acta 58 (9), 2041-2060.

Smith, A.B., 1984. Echinoid Palaeobiology. Special Topics in Palaeontology. George Allen and Unwin, London, England, p. 202.

Smith, A.B., Kroh, A., 2011. The Echinoid Directory. World Wide Web electronic publication. http://www.nhm.ac.uk/research-curation/projects/echinoid-directory. (Accessed 20 January 2019).

Smith, A.B., Stockley, B., 2005. Fasciole pathways in spatangoid echinoids: a new source of phylogenetically informative characters. Zool. J. Linn. Soc. 144, 15-35.

Stara, P., Sanciu, L., Rizzo, R., 2012. Segnalazione di una associazione ad echinidi con spatangoidi prevalenti in Sardegna. Notiziario della Società Reggiana di Scienze Naturali 2010, 27-42.

Stara, P., Borghi, E., Kroh, A., 2016. Revision of the genus Mariania (Echinoidea) with the description of two new species from the Miocene of Italy. Bull. Geosci. 91 (1), 65-88.

Stockley, B., Smith, A.B., Littlewood, T., Lessios, H.A., MacKenzie-Dodds, J.A., 2005. Phylogenetic relationships of spatangoid sea urchins (Echinoidea): taxon sampling density and congruence between morphological and molecular estimates. Zool. Scripta 34, 447-468.

The Document Foundation, 2020. LibreOffice calc. https://www.libreoffice.org/discove $\mathrm{r} / \mathrm{calc}$.

Villier, L., Néraudeau, D., Clavel, B., Neumann, C., David, B., 2004. Phylogeny of early cretaceous spatangoids (echinodermata: Echinoidea) and taxonomic implications. Palaeontology 47 (2), 265-292.

Yong Technologies Inc., 2015. GeoRose 0.4. 3 - Rose Plot Software. http://www. yongtechnology.com/georose/. 